\title{
Productivity patterns and N-fixation associated with Pliocene-Holocene sapropels: paleoceanographic and paleoecological significance
}

\author{
D. Gallego-Torres ${ }^{1,5}$, F. Martinez-Ruiz ${ }^{2}$, P. A. Meyers ${ }^{3}$, A. Paytan ${ }^{4}$, F. J. Jimenez-Espejo ${ }^{2}$, and M. Ortega-Huertas ${ }^{5}$ \\ ${ }^{1}$ Utrecht University Faculty of Geosciences (Department of Earth Sciences - Geochemistry) Budapestlaan, 4, 3508 TA \\ Utrecht, The Netherlands \\ ${ }^{2}$ Instituto Andaluz de Ciencias de la Tierra (CSIC-UGR) Facultad de Ciencias, Campus Fuentenueva, 18002 Granada, Spain \\ ${ }^{3}$ Department of Geological Sciences, The University of Michigan, Ann Arbor, MI 48109-1005, USA \\ ${ }^{4}$ Institute of Marine Sciences, Earth \& Planetary Sciences Department, Univ. of Santa Cruz Santa Cruz, CA 95064, USA \\ ${ }^{5}$ Departamento de Mineralogía y Petrología, Facultad de Ciencias, Universidad de Granada, Campus Fuentenueva, 18002 \\ Granada, Spain
}

Received: 17 May 2010 - Published in Biogeosciences Discuss.: 11 June 2010

Revised: 25 November 2010 - Accepted: 31 January 2011 - Published: 16 February 2011

\begin{abstract}
We have studied a suite of 35 sapropel sequences from a transect of four ODP sites across the Eastern Mediterranean to explore for paleoproductivity patterns and provide new insights on ecological changes during their deposition. Paleoproductivity variations were identified using TOC and $\mathrm{Ba}_{\text {bio }}$ mass accumulation rates and $\delta^{15} \mathrm{~N}_{\text {total }}$ and $\delta^{13} \mathrm{C}_{\mathrm{org}}$ values. Elevated $\mathrm{Ba} / \mathrm{Al}$ and TOC mass accumulation rates record periods of basin-wide amplified productivity. Our data further support that sapropels were formed by cyclic increases in primary production of marine organic matter largely sustained by $\mathrm{N}$-fixing bacteria. This productivity increase was triggered by climate factors leading to increased fluvial discharge and amplified nutrient input that also favored the establishment of $\mathrm{N}$-fixing bacteria. Enhanced productivity led to depletion of deepwater dissolved oxygen and consequently improved organic matter preservation. Primary production was more intense during the middle to Late Pleistocene compared to Pliocene equivalents, coinciding with increasing total sedimentation rates. $\delta^{15} \mathrm{~N}$ values are dramatically lower in the sapropels than in TOC-poor background sediments, indicating a major contribution from nitrogenfixing bacteria to the higher productivity during sapropel deposition. Additionally, different degrees of denitrification occurred as a consequence of water column oxygenation which in turns evolved from stagnant anoxic bottom waters during Pliocene sapropels to oxygen depleted and sluggish circu-
\end{abstract}

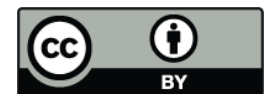

Correspondence to: D. Gallego-Torres (d.gallego@geo.uu.nl) lation in late Quaternary layers. These differences between sapropel layers provide new evidences for the general evolution of the Eastern Mediterranean basin during the last 3 Mys in terms of paleoceanographic conditions and the intensity of climate variability leading to sapropel deposition.

\section{Introduction}

The multiple sapropel layers that were deposited in the Neogene-Quaternary Mediterranean basin are of particular interest to the topic of enhanced organic carbon accumulation in marine sediment. Sapropels, as defined by Kidd (1978), are cyclically deposited dark colored sediment layers that are more than $2 \mathrm{~cm}$ in thickness and contain more than $2 \%$ total organic carbon (TOC). A debate about whether improved preservation or elevated productivity is the major cause for high concentrations of organic matter in such sediments has persisted in paleoceanographic studies for decades (e.g., Casford et al., 2003; de Lange et al., 2008; Emeis and Weissert, 2009; Jenkins and Williams, 1984; Mangini and Schlosser, 1986). The traditional interpretation of sedimentary layers rich in organic matter as representative of anoxic events has been challenged by Pedersen and Calver, (1990; see also Calvert et al., 1996; Calvert and Pedersen, 1993), who argued that increased productivity, rather than absence of oxygen, was the primary factor responsible for the enhanced accumulation of organic carbon in sediments. Indeed, sapropel deposition is usually considered to be related to an increase in marine export productivity (e.g., Calvert et

Published by Copernicus Publications on behalf of the European Geosciences Union. 
al., 1992; Diester-Haass et al., 1998; Lourens et al., 1992; Martínez-Ruiz et al., 2000, 2003; Meyers and Arnaboldi, 2005; Weldeab et al., 2003a, b). However, how marine productivity increased in a presently oligotrophic, nutrient deficient basin like the Mediterranean raises questions regarding the sources of nutrient that have fueled this productivity increase (e.g., Casford et al., 2003; Filippelli et al., 2003; Menzel et al., 2003; Sachs and Repeta, 1999; Tanaka et al., 2010).

Development of a number of geochemical paleoproductivity proxies that are independent of oxygen abundance has allowed reconstruction of productivity and improved interpretation of the causal mechanisms of organic matter accumulation. Among these proxies, barium excess $\left(\mathrm{Ba}_{\mathrm{bio}}\right)$, and biogenic barite accumulation (e.g., Dehairs et al., 1987; Dymond and Collier, 1996; Dymond et al., 1992; McManus et al., 1998; Paytan and Kastner, 1996), and nitrogen content and isotopic composition (e.g., Altabet and Francois, 1994; Arnaboldi and Meyers, 2006; Calvert et al., 1992; Meyers and Bernasconi, 2005; Peters et al., 1978) have been found especially useful in a variety of paleoceanographic settings. In recent years several papers have employed some of these paleoproductivity proxies to describe spatial and temporal patterns of sapropel deposition (e.g., Arnaboldi and Meyers, 2006; Meyers and Bernasconi, 2005; Rinna et al., 2002; Struck et al., 2001). However, further comparisons of the isotopic and elemental proxies and $\mathrm{Ba}_{\text {bio }}$, paleoproductivity proxy most widely used in the Mediterranean, and additional documentation of any differences of these signals during the paleoceanographic evolution of the basin are important to resolve existing questions about the conditions under which sapropels were deposited.

In this paper, we describe the results of our analyses of a suite of 35 sapropels of different ages that span the Pliocene through the Holocene and that originate from a four-site transect across the Eastern Mediterranean Basin. The description of the spatial and temporal patterns of export productivity in sapropel deposition is interpreted in terms of their possible paleoceanographic significance. We correlate both organic $\mathrm{C}$ and total $\mathrm{N}$ content and isotope signatures $\left(\delta^{15} \mathrm{~N}\right.$ and $\left.\delta^{13} \mathrm{C}\right)$ to complement the information given by $\mathrm{Ba} / \mathrm{Al}$, and we employ TOC and Babio mass accumulation rates (MAR's) to refine paleoproductivity patterns. The effect of diagenesis on sediment $\mathrm{N}$ and $\mathrm{C}$ contents is also considered, inasmuch as organic matter is susceptible to post-depositional oxidation and alteration (e.g., Martínez-Ruiz et al., 2000; Thomson et al., 1995; Van Santvoort et al., 1996).

\section{Materials and methods}

\subsection{Sample settings}

Sapropel sequences were sampled in cores recovered at four ODP Leg 160 sites (Fig. 1) that represent different oceanographic regimes within the Eastern Mediterranean Sea. To

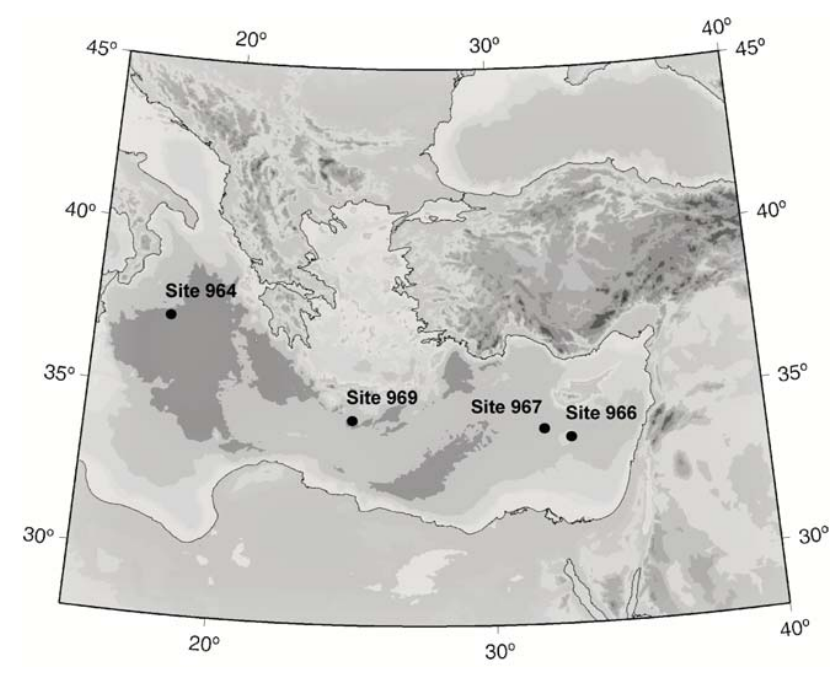

Fig. 1. Location map for the 4 studied sites. Site 964 (lonian basin) is the deepest studied location. 966 is located on a pelagic high, the Erathostenes Seamount (see text for details).

summarize, the sedimentary sequence deposited at Site 964, located in a deep marine setting (3658 m.b.s.l.) on the Pisano Plateau (Ionian Basin), is influenced by the Adriatic Sea and the water masses coming from the Western Mediterranean basin through the Strait of Sicily. Site 969, also in a relatively deep, open marine setting (2200 m.b.s.l.) on the Mediterranean Ridge, represents the centermost location in the Eastern Mediterranean. Cores recovered at Site 967 in the Levantine Basin, although containing a sequence of deep pelagic sediments ( 2555 m.b.s.l.), are influenced by detrital input from the Nile River, which drains the central African craton. Finally, Site 966 is situated on a pelagic high, the Eratosthenes Seamount, at the relatively shallow water depth of 926 m.b.s.l. At each site, high resolution sampling was carried out on selected sapropel-containing core intervals. These sections represent late Pleistocene and Holocene periods of sapropel deposition at all four sites, Lower Pleistocene layers at sites 969 and 967 and Pliocene layers for sites 964 and 969.

The sediments in these cores are composed mostly of variably bioturbated nannofossil clay, clayey nannofossil ooze and nannofossil ooze with some intervals of clay and foraminifera sand, variably bioturbated (Emeis et al., 1996). Dark colored to black sapropel layers appear periodically throughout the pelagic sequences. Some of these TOCenriched sediments and sections of the overlying and underlying sediment from these cores were sampled at $2 \mathrm{~cm}$ intervals. Where lamination allowed, samples were collected at a resolution as fine as $1 \mathrm{~mm}$. 


\subsection{Analysis}

Samples were dried, homogenized in an agate mortar, and then subdivided for different analyses. TOC measurements for some samples were carried out using a Perkin-Elmer Elemental analyzer at the Stable Isotope Laboratory at Stanford University (Mucciarone, 2003). The rest of the samples were analyzed for total carbon (TC) and TOC separately at Bremen University using a TOC/TC analyzer. TOC was measured on the TOC/TC analyzer after acidification of sediment with $1 \mathrm{~N} \mathrm{HCl}$ to remove carbonates followed by heating to dryness. At Stanford University, parallel to TOC measurements, total $\mathrm{N}(\mathrm{TN}), \delta^{13} \mathrm{C}$ and $\delta^{15} \mathrm{~N}$ isotopic composition were also carried out using a Finnigan MAT isotope ratio mass spectrometer (IRMS) connected to a Carlo Erba (now CE Elantech, Inc.) NA1500 Series II Elemental Analyzer. TOC/TN ratios are expressed on an atom/atom basis. $\delta^{15} \mathrm{~N}$ and $\delta^{13} \mathrm{C}$ values are respectively expressed relative to atmospheric dinitrogen and Vienna PeeDee Belemnite (VPDB) standards. These samples were repeatedly acidified with $\mathrm{HSO}_{3}$ to eliminate all inorganic carbon prior to isotope analysis.

Barium content was determined using an ICP-MS PerkinElmer Sciex Elan 5000 spectrometer (CIC; Analytical Facilities of the University of Granada), using Re and Rh as internal standards. Coefficients of variation calculated by dissolution and subsequent analyses of 10 replicates of powdered samples were better than $3 \%$ and $8 \%$ for analyte concentrations of 50 and 5 ppm, respectively (Bea, 1996). Aluminium content was analyzed by atomic absorption spectrometry at the Analytical Facilities of the University of Granada. These two analyses were carried out after $\mathrm{HNO}_{3}$ and $\mathrm{HF}$ total digestion of the homogenized sample. Biogenic $\mathrm{Ba}\left(\mathrm{Ba}_{\mathrm{bio}}\right)$ was calculated following the equation used by Wehausen and Brumsack (1999) in order to separate detrital barite from barium precipitated as biogenic barite.

Ages of individual sapropel layers and site to site age correlations are based on precessional age scales in Emeis et al. (2000a), Lourens (2004), and Sakamoto et al. (1998). Each sampled layer was directly assigned to the corresponding sapropel name and insolation cycle (i-cycle) using Tables 1 to 4 from Emeis et al. (2000a) on the basis of sample to sample correlation (using ODP nomenclature) and/or revised composite core depths, or correlated using core tie points obtained from the ODP online database.

TOC and Babio MAR's were calculated based on the sediment dry bulk density (DBD) obtained from the ODP Leg 160 database (available online) and linear sedimentation rates (LSR), calculated from age models from the database: MAR $=$ DBD $*$ LSR. When borehole LSR were not available, they were calculated for our sampling intervals, either using adjacent age intervals (again obtained from the ODP online database) or based on the methodology used by Meyers and Arnaboldi (2005). In brief, the peak TOC MAR calculated in each sapropel layer was assumed to represent the orbitally
Table 1. Summary of analyzed sapropel layers with their correspondent depth, assigned insolation cycle, age (mid-point) and calculated Linear Sedimentation Rate (LSR) for each interval.

\begin{tabular}{|c|c|c|c|c|c|}
\hline Sample Location & I-Cycle & $\begin{array}{l}\text { *Age sapropel } \\
\text { midpoint (ka) }\end{array}$ & $\begin{array}{l}\text { Depth } \\
\text { (mbsf) }\end{array}$ & $\begin{array}{l}\text { Depth } \\
\text { (mcd) }\end{array}$ & $\begin{array}{c}\text { LSR } \\
(\mathrm{cm} / \mathrm{ky})\end{array}$ \\
\hline \multicolumn{6}{|c|}{ Site 964, Ionian Basin (3658 m.b.s.1.) } \\
\hline Hole 964A & i-c 2 & 7.75 & 0.73 & 0.73 & 4.14 \\
\hline Hole $964 \mathrm{~A}$ & i-c 12 & 124 & 7.71 & 7.81 & 5.93 \\
\hline Hole $964 \mathrm{~A}$ & i-c 16 & 172 & 11.12 & 11.22 & 6.00 \\
\hline Hole $964 \mathrm{~A}$ & i-c 18 & 195 & 11.99 & 12.09 & 4.04 \\
\hline Hole $964 \mathrm{~A}$ & i-c 20 & 217 & 12.62 & 12.72 & 3.02 \\
\hline Hole $964 \mathrm{~A}$ & i-c 272 & 2828 & 76.73 & 98.21 & 2.55 \\
\hline Hole $964 \mathrm{~A}$ & i-c 282 & 2943 & 79.64 & 101.12 & 2.41 \\
\hline Hole $964 \mathrm{~A}$ & i-c 284 & 2965 & 80.19 & 101.67 & 2.87 \\
\hline Hole 964A & i-c 286 & 2989 & 80.93 & 102.41 & 2.50 \\
\hline \multicolumn{6}{|c|}{ Site 966. Eratosthenes Seamount (926 m.b.s.1.) } \\
\hline Hole 966B & i-c 2 & 8.26 & 0.27 & 0.27 & 3.90 \\
\hline Hole 966B & i-c 8 & 81 & 2.36 & 2.36 & 2.60 \\
\hline Hole 966B & i-c 12 & 124 & 3.31 & 3.31 & 2.35 \\
\hline Hole 966B & i-c 16 & 172 & 4.36 & 4.36 & 2.19 \\
\hline Hole 966B & i-c 18 & 195 & 4.78 & 4.78 & 2.24 \\
\hline Hole 966B & i-c 20 & 217 & 5.45 & 5.45 & 2.04 \\
\hline \multicolumn{6}{|c|}{ Site 967. Levantine Basin (2555 m.b.s.1.) } \\
\hline Hole 967D & i-c 2 & 7.94 & 1.17 & 1.17 & 5.36 \\
\hline Hole 967D & i-c 8 & 81 & 4.32 & 4.28 & 5.64 \\
\hline Hole 967D & i-c 10 & 102 & 5.65 & 5.58 & 5.90 \\
\hline Hole 967D & i-c 16 & 172 & 10.57 & 9.79 & 4.67 \\
\hline Hole 967D & i-c 170 & 1736 & 47.76 & 52.96 & 2.20 \\
\hline Hole 967C & i-c 172 & 1757 & 48.21 & 53.41 & 2.58 \\
\hline Hole 967C & i-c 176 & 1808 & 49.35 & 54.55 & 1.92 \\
\hline Hole 967C & i-c 178 & 1829 & 49.89 & 55.09 & 2.42 \\
\hline Hole 967C & i-c 180 & 1851 & 50.35 & 55.55 & 2.30 \\
\hline Hole 967C & i-c 182 & 1872 & 50.87 & 56.07 & 2.18 \\
\hline \multicolumn{6}{|c|}{ Site 969. Mediterranean Ridge (2200 m.b.s.l.) } \\
\hline Hole 969A & i-c 2 & 7.98 & 0.27 & 0.27 & 4.39 \\
\hline Hole 969A & i-c 10 & 102 & 2.64 & 2.42 & 4.36 \\
\hline Hole 969A & i-c 12 & 124 & 3.92 & 3.41 & 4.24 \\
\hline Hole 969A & i-c 16 & 172 & 5.65 & 4.94 & 2.62 \\
\hline Hole 969A & i-c 18 & 195 & 6.16 & 5.48 & 2.64 \\
\hline Hole 969A & i-c 152 & 1564 & 27.05 & 34.05 & 2.80 \\
\hline Hole 969A & i-c 160 & 1642 & 28.54 & 36.19 & 2.75 \\
\hline Hole 969A & i-c 280 & 2921 & 50.74 & 73.25 & 1.88 \\
\hline Hole 969E & i-c 284 & 2965 & 51.48 & 73.96 & 2.37 \\
\hline
\end{tabular}

*Ages are from Lourens et al. (1996) and de Kaenel et al. (1999) and are based on the orbital calculations. S1 age is based on De Lange et al. (2008).

tuned age of the corresponding i-cycle. For sapropel 1, the age model obtained by de Lange et al. (2008) was applied, whereas for each of the rest of the analyzed sapropels, its corresponding i-cycle was assigned following the nomenclature and ages defined by Emeis et al. (2000a). The difference in core depths between successive sapropel layers was then divided by the $\sim 21 \mathrm{ky}$ of each precessional cycle to arrive at a linear sedimentation rate for this time and place. This method is consistent with the age model published by Lourens (2004) although it may sometimes contradict the 
assumptions of sapropel synchronicity considered by other authors (e.g., Cane et al., 2002; Capotondi et al., 2006; de Lange et al., 2008; Emeis et al., 2003). The LSRs used for MAR calculations are summarized in Table 1.

\section{Results}

\subsection{TOC concentrations and MAR's}

TOC concentrations in the samples range from less than $0.1 \%$ in the background sediment up to $28.4 \%$ in one sapropel layer (Figs. 2 to 6), with the highest values detected in the Pliocene sapropels at sites 964 and 969. The general temporal trend is a progressive increase in sapropel TOC concentrations from the Holocene through the Late Pleistocene (Figs. 2 to 5) and into the Early Pleistocene and Pliocene (Fig. 6). At each site, TOC-MARs show maximum values in Pliocene sapropels. For sapropels deposited during the same insolation cycle, those at Site 966 have the lowest TOC concentrations and lowest TOC MARs (see Fig. 2 to 5).

\subsection{Organic carbon isotopic compositions}

The $\mathrm{C}_{\text {org }}$-isotopic compositions of the sapropel sequences differ spatially and temporally (see Figs. 7 to 11). As a whole, $\delta^{13} \mathrm{C}$ values range between $-19.0 \%$ and $-26.5 \%$, and both the highest and lowest values are found within the Late Pleistocene sapropels sampled from Site 967. Although a general trend of increasing $\delta^{13} \mathrm{C}$ values appears at sites 964 and 966, this tendency is not observed for Site 967 nor in the Pliocene S53 at Site 969. An apparent shift towards higher C-isotopic compositions occurs at the base of the Quaternary sapropels or just before the increase in their TOC content.

\subsection{Nitrogen isotopic compositions}

The $\delta^{15} \mathrm{~N}$ values are strikingly similar at all four locations. They are significantly lower in the TOC rich sections compared to the carbonate oozes. The $\delta^{15} \mathrm{~N}$ values range from $\approx 1.0$ to 0.0 for the sapropel 1 (i-cycle 2) (Fig. 7) to between $0 \%$ to $-3.0 \%$ o for Pleistocene sapropels (see Figs. 8 to 10) as low as $-3.1 \%$ in the Pliocene sapropels (Fig. 11). When same i-cycles are compared between sites, $\delta^{15} \mathrm{~N}$ values are very similar; only those values at Site 966 tend to be slightly higher.

\subsection{Ba concentrations and MAR's}

Barium concentrations vary in parallel with TOC concentrations (Figs. 2 to 5), although elevated Ba concentrations frequently extend above the organic enriched layer in late Quaternary sapropels (Fig. 2), a feature especially visible in sapropels from Site 966. The sapropel layers at this site show a distinct offset between organic carbon accumulation and the productivity signal as represented by $\mathrm{Ba} / \mathrm{Al}$. In contrast to the patterns common to the late Quaternary sapropels, $\mathrm{Ba}_{\text {bio }}$ values decrease more than TOC MARs near the tops of Pliocene sapropels at sites 964 and 969 (Figs. 6 and 11). Because of the different patterns in the two proxies, we estimated durations of the sapropel formation events by measuring the Ba peak width in the Holocene and Late Pleistocene sapropels and the TOC MAR peak in the Early Pleistocene and Pliocene sapropels.

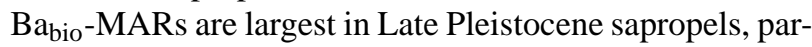
ticularly during i-cycle 12 (S5, see Fig. 3). The highest $\mathrm{Ba}_{\mathrm{bio}^{-}}$ MARs values are found at Site 964, the deepest studied site. For same-age sapropels, the increases in $\mathrm{Ba}_{\mathrm{bio}}$-MAR are similar for the three sites located in the deeper parts of the basin, but they are notably lower at shallower Site 966 (Figs. 2 to 5).

\section{$3.5 \quad \mathrm{TOC} / \mathrm{TN}$ ratios}

The atomic TOC/TN ratio varies similarly through time at the four locations, showing values mostly between 5 and 10 for background "normal" pelagic sediment (carbonate ooze), and increasing up to 25 in the sapropels (see Figs. 6 to 11). The highest sapropel TOC/TN ratios are found at Site 967, whereas the lowest are found at the bathymetrically elevated Site 966.

\section{Discussion}

\subsection{Paleoproductivity proxies}

\subsection{1 $\delta^{13} \mathrm{C}$ patterns and paleoceanographic significance}

Organic $\delta^{13} \mathrm{C}$ values in analyzed sediment samples mostly correspond to organic matter of marine origin, although some terrestrial influence might be argued. However, $\delta^{13} \mathrm{C}$ values lower than $-23 \%$ are common across the Eastern Mediterranean, especially in low TOC sections. The more negative values are consistent with an oligotrophic setting in which $\mathrm{C}$ availability does not limit algal vital fractionation. In contrast, periods of higher productivity result in depletion of ${ }^{12} \mathrm{C}$ from increased uptake, increasing $\delta^{13} \mathrm{C}_{\text {org }}$ values (e.g., Meyers, 1997). This slight increase in $\delta^{13} C_{\text {org }}$ values is the general response found in analyzed sapropels and is particularly evident at the base of the $\mathrm{C}_{\text {org }}$-rich layers. This classic high-productivity isotopic trend is not evident at Site 967. Instead, cores recovered at this deep Levantine sub-basin location exhibit generally lower $\delta^{13} \mathrm{C}_{\text {org }}$ values and the most erratic trends in the sample suite. A possible explanation is that extensive organic matter recycling in the surface ocean limited the ${ }^{13} \mathrm{C}$ enrichment associated with net uptake (e.g., Arnaboldi and Meyers, 2006; Menzel et al., 2003; Meyers and Arnaboldi, 2008; Struck et al., 2001) which can also apply to slight decreases in the upper part of some sapropel layers (e.g., S49, Site 969). Increased continental runoff associated 


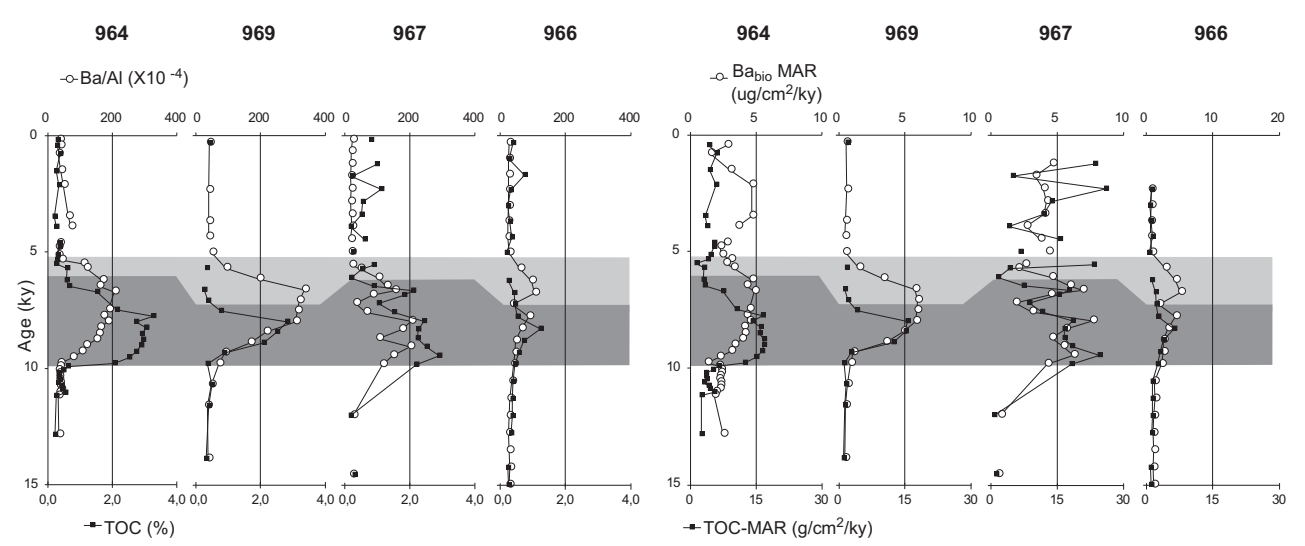

Fig. 2. Comparison of TOC and Ba/Al vs. TOC-MAR and Ba bio MAR for S1 on the four studied sites. Dark shade corresponds to visible sapropel layer. Light shade represents oxydized sapropel.
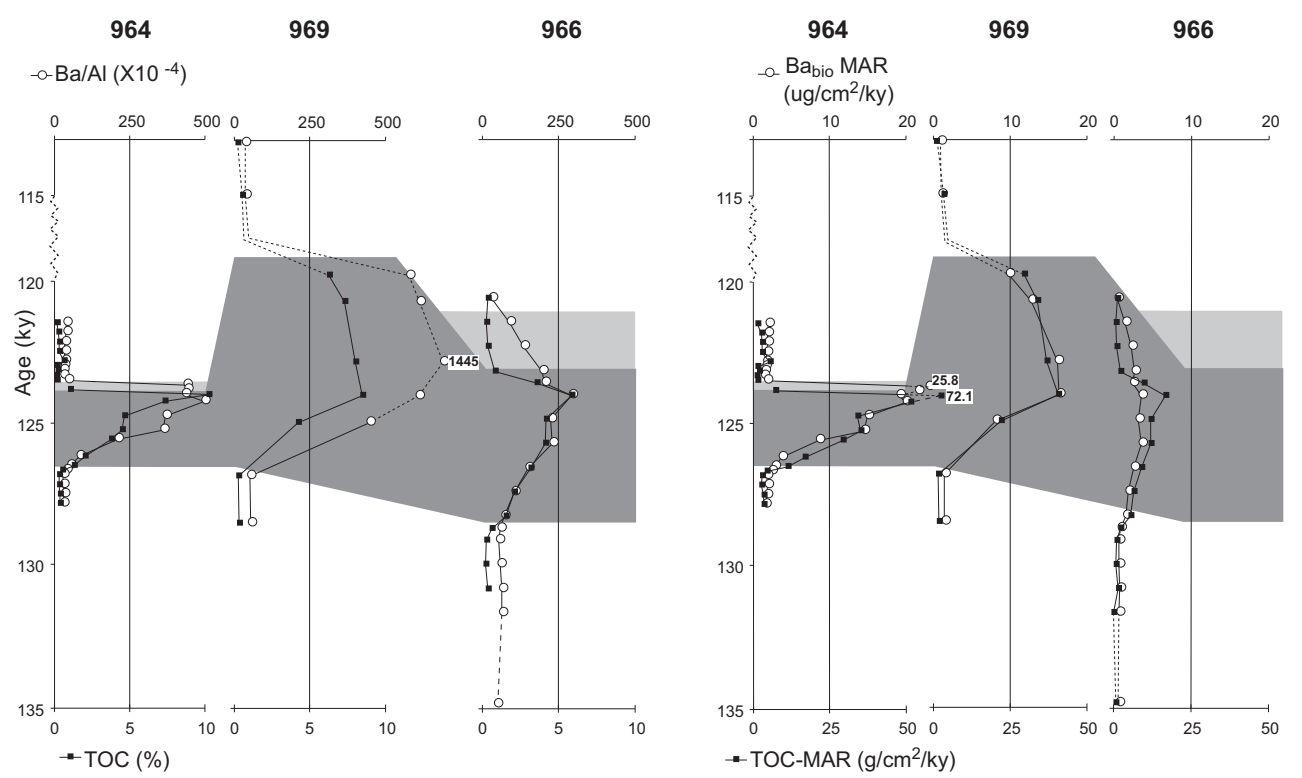

Fig. 3. Comparison of TOC and Ba/Al vs. TOC-MAR and Ba bio MAR for S5 on three studied sites. Dark shade corresponds to visible sapropel layer. Light shade represents oxydized sapropel. Maximum values off-scale are numerically indicated on the graph.

with periods of sapropel formation (e.g., Gallego-Torres et al., 2010; Rossignol-Strick, 1985) lowered the salinity of the surface ocean and created a strongly stratified water column that impeded sinking of organic matter and discouraged vertical mixing. Oxidation of the isotopically light organic carbon could then occur within the lower part of the photic zone, where it could be re-assimilated by photosynthesizers. The near-surface recycling of marine organic carbon during times of fluvial dilution of the surface ocean would potentially be augmented by delivery of low ${ }^{13} \mathrm{C}$ terrestrial organic matter, this site being under the influence of the distal plume of the Nile River, adding to the low isotope signal. In any case, a shift toward higher isotopic composition is visible at the base of the TOC-enriched layers at Site 967, which is a clas- sical indication of a general increase in ${ }^{12} \mathrm{C}$ removal in the form of marine organic matter during initiation of sapropel deposition.

\subsubsection{Paleoproductivity evidence from nitrogen concentrations}

Total nitrogen in sediment indicates organic matter production, provided $\mathrm{N}$ adsorbed to clay minerals is insignificant (e.g., Calvert, 2004; de Lange, 1992; Freudenthal et al., 2001). This was verified using the correlation method described by Nijenhuis and de Lange (2000), Calvert (2004), and Arnaboldi and Meyers (2006) in which the concentrations of TOC are plotted against those of TN. The correlation is extremely good $(R>0.9$ for all cores, see Fig. 12) with an 


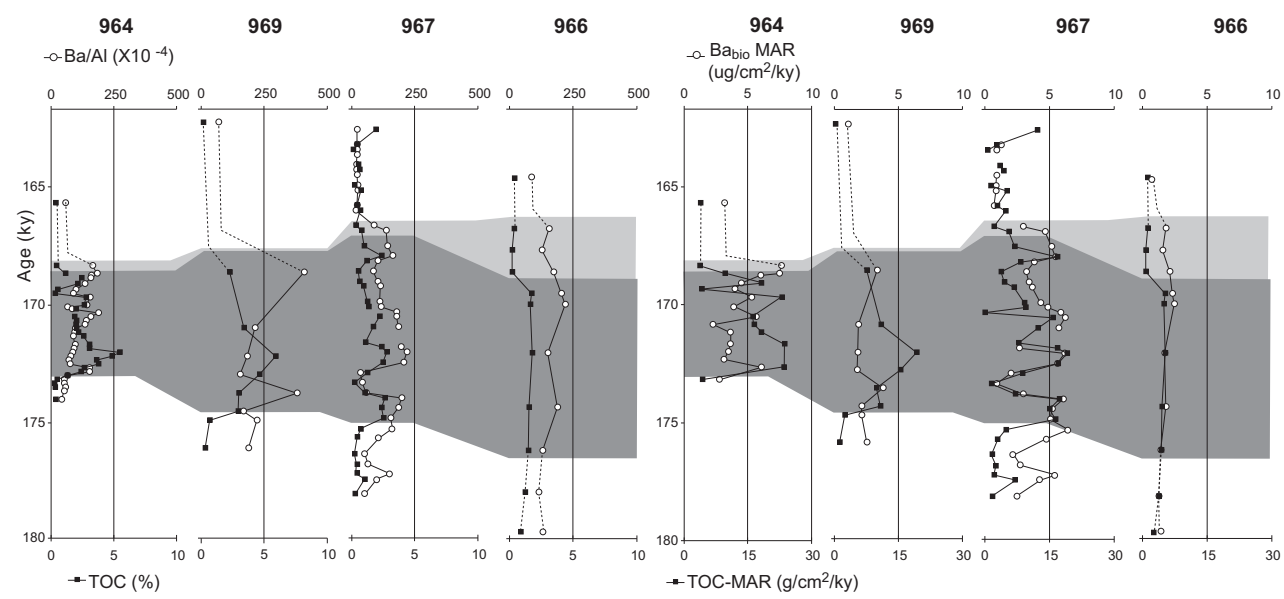

Fig. 4. Comparison of TOC and Ba/Al vs. TOC-MAR and Babio MAR for S6 on all studied sites. Dark shade corresponds to visible sapropel layer. Light shade represents oxydized sapropel.
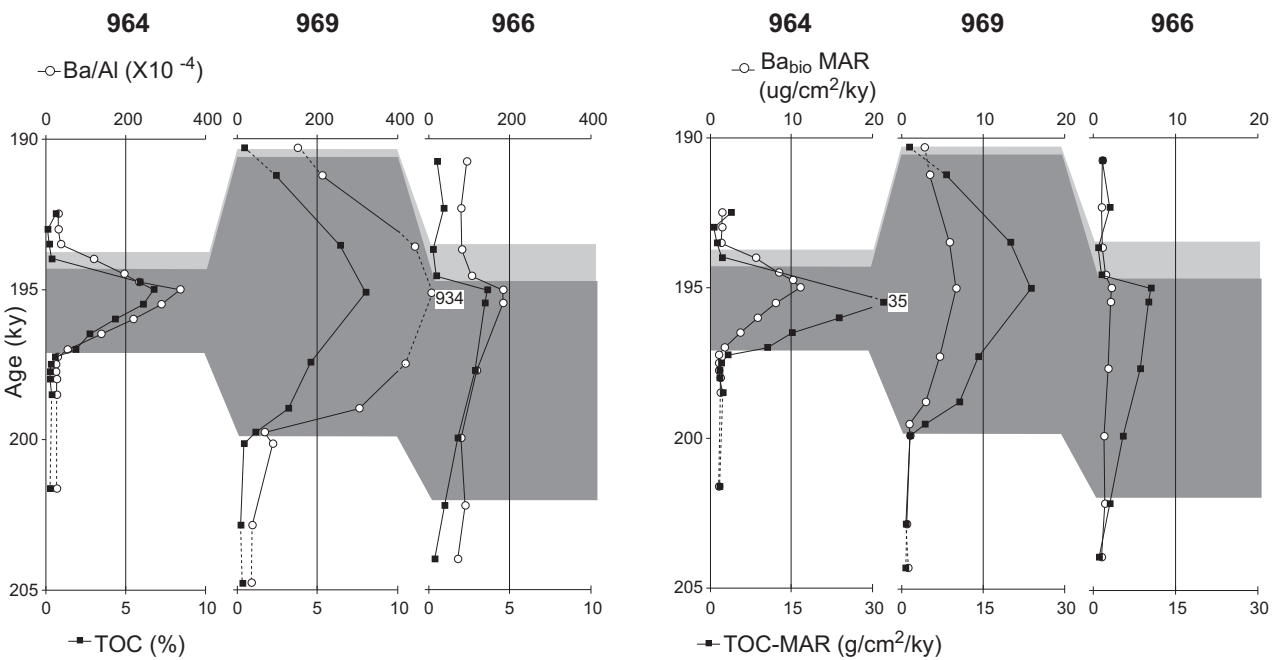

Fig. 5. Comparison of TOC and Ba/Al vs. TOC-MAR and Ba bio MAR for S7 on three studied sites. Dark shade corresponds to visible sapropel layer. Light shade represents oxydized sapropel. Maximum values off-scale are shown on the graph.

intersection essentially at the origin of the $y$ axis. Although this intersection point is not exactly zero, the amount of inorganic $\mathrm{N}$ is negligible, as $\mathrm{C}: \mathrm{N}$ ratios of low TOC samples are within the range of previous studies (e.g., Meyers and Arnaboldi, 2005) and in agreement with expected Redfield ratios.

Because organic $\mathrm{N}$ is also susceptible to post-depositional oxidation similar to organic carbon, its use for paleoproductivity reconstruction is subject to the same restrictions. Nonetheless, the correlation between TN and TOC gives us confidence that the entire $\mathrm{N}$ in the sediment is associated with or derived from organic matter, and so our $\delta^{15} \mathrm{~N}$ analyses will reflect purely $\mathrm{N}_{\text {org }}$.

\subsection{3 $\delta^{15} \mathrm{~N}$ patterns in sapropel sequences}

The $\mathrm{N}_{\text {org }}$ isotopic composition can be used as an indicator for the origin of organic matter (e.g., Knicker and Hatcher, 2001; Meyers, 1997; Rinna et al., 2002; Schubert and Calvert, 2001) and, more importantly, for evaluating nutrient cycles in the water column (e.g., Altabet et al., 1999; Altabet and Francois, 1994; Freudenthal et al., 2001; Karl et al., 2002; Pantoja et al., 2002; Voss et al., 1996). The Mediterranean is presently an oligotrophic sea, characterized by low concentrations of macro-nutrients such as $\mathrm{P}$ and $\mathrm{N}$ in surface waters (e.g., Astraldi et al., 2002; Bethoux, 1989; Struck et al., 2001). This shortage of nutrients, as a whole and of $P$ specifically, is particularly dramatic in the Eastern Basin. An important regional nutrient source to the Eastern Mediterranean is the Nile River (e.g., Diester-Haass et al., 1998; Jenkins 

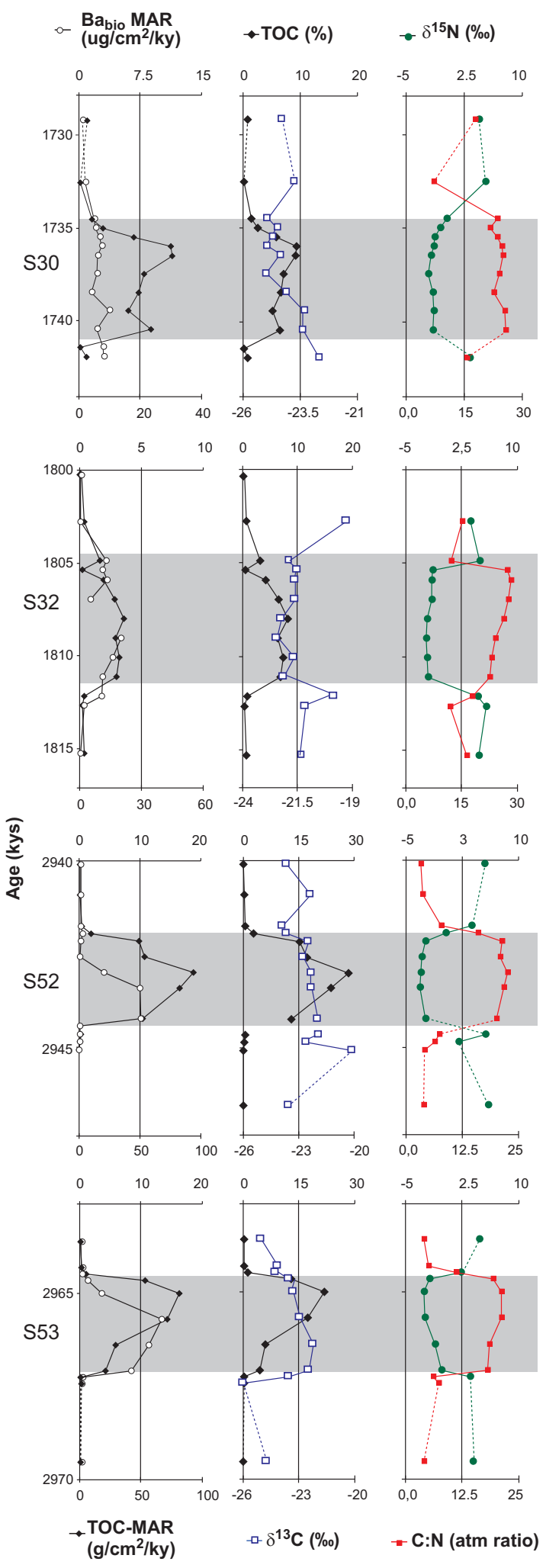

Fig. 6. Geochemical signal and TOC and $\mathrm{Ba}_{\text {bio }}$ Mass Accumulation Rates, C:N, and $\mathrm{C}-\mathrm{N}$ isotopic composition for representative Lower Pleistocene from Site 967 and Pliocene sapropels from Site 964. Note different scales for TOC and Ba-MAR's. Shaded areas correspond to sapropel layers. and Williams, 1984; Rossignol-Strick, 1985; Weldeab et al., 2003a). This riverine input of nutrients has fluctuated over time as cyclic intensification in the monsoon system during insolation maxima increased runoff from its catchment (e.g., Hilgen, 1991; Rohling and Hilgen, 1991; Rossignol-Strick, 1985). With respect to $N$, nitrogen fixation and possibly atmospheric deposition are currently important sources for bioavailable $\mathrm{N}$ to the oligotrophic Mediterranean, although their significance is also variable over space and time.

Organic matter in all the sapropels exhibits a shift to $\delta^{15} \mathrm{~N}$ values lower than in the background marls at the four locations (Figs. 6 to 11). This signature is unlikely a result of diagenesis as under suboxic-anoxic water column conditions the expected trend of organic matter degradation is an increase in $\delta^{15} \mathrm{~N}$ due to remineralization that is associated with an increase in TOC/TN ratios (e.g., Karl et al., 2002; Lehmann et al., 2002; Meyers and Arnaboldi, 2005; Nakatsuka et al., 1997). Moreover, Higgins et al. (2010) recently rejected the possible diagenetic overprinting by measuring chlorin $\delta^{15} \mathrm{~N}$ in sapropels and marls. Instead, the possible explanations for the dramatic decrease in ${ }^{15} \delta \mathrm{N}$ values in the sapropels are: (a) incomplete nutrient utilization under nutrient excess conditions (e.g., Calvert et al., 1992), (b) an external source of light $\mathrm{N}$ such as river discharge or atmospheric deposition (e.g., Krom et al., 2004; Mara et al., 2009), and (c) an ecosystem change in which a bloom of nitrogen-fixing primary producers occurs (e.g., Arnaboldi and Meyers, 2006; Milder et al., 1999; Pantoja et al., 2002; Sachs and Repeta, 1999; Struck et al., 2001).

The evidence for increased productivity based on the high TOC and Ba concentrations of the sapropels is strong so we may reject the hypothesis of incomplete nitrogen utilization. Fluvial delivery is also unlikely as an extraordinary excess of nutrients would have to be delivered to lower the $\delta^{15} \mathrm{~N}$ values, particularly considering the amount of organic carbon accumulated in the sapropels (Sachs and Repeta, 1999). Increase in atmospheric deposition of nitrogen is also unlikely as it is expected that less dust would be mobilized during the wetter climate associated with precessional minima. In addition much of the atmospheric nitrogen sources today are anthropogenic and thus atmospheric deposition was not as important in pre-anthropogenic times. Accordingly we believe that nitrogen fixation is the main source of the bioavailable nitrogen with low isotope values in surface waters (e.g., Altabet and Francois, 1994; Kuypers et al., 2004; Milder et al., 1999). This process would incorporate dissolved atmospheric dinitrogen $\left(\delta^{15} \mathrm{~N}=0 \%\right.$ ) into the marine system, lowering the isotopic composition (e.g., Altabet et al., 1999; Karl et al., 2002; Meyers, 1997; Pantoja et al., 2002). The extremely light $\mathrm{N}$ isotopic composition suggests a change in the photoautotrophic community to a primarily $\mathrm{N}$-fixing biota, probably associated with a decrease in eukaryote phytoplankton activity during sapropel deposition times (e.g., Milder et al., 1999; Pantoja et al., 2002; Sachs and Repeta, 1999). Nitrogen fixing cyanobacteria, cyanobacterial mats 


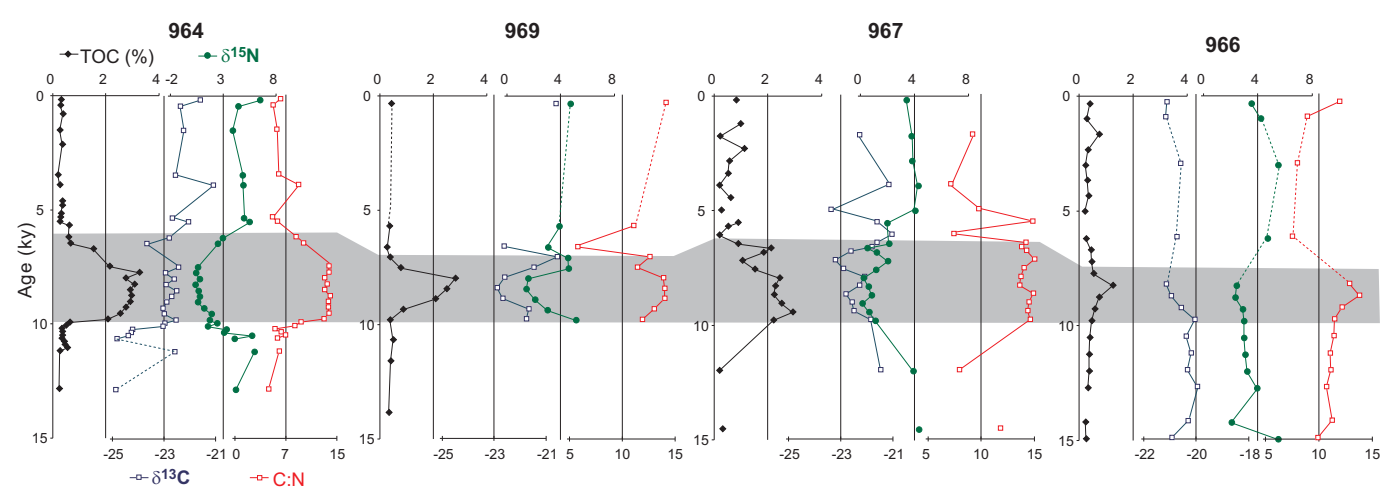

Fig. 7. TOC, $\mathrm{C}$ and $\mathrm{N}$ ratio, $\delta^{15} \mathrm{~N}, \delta^{13} \mathrm{C}$ for $\mathrm{S} 1$ at all studied sites. Shaded area corresponds to organic enriched sediments.

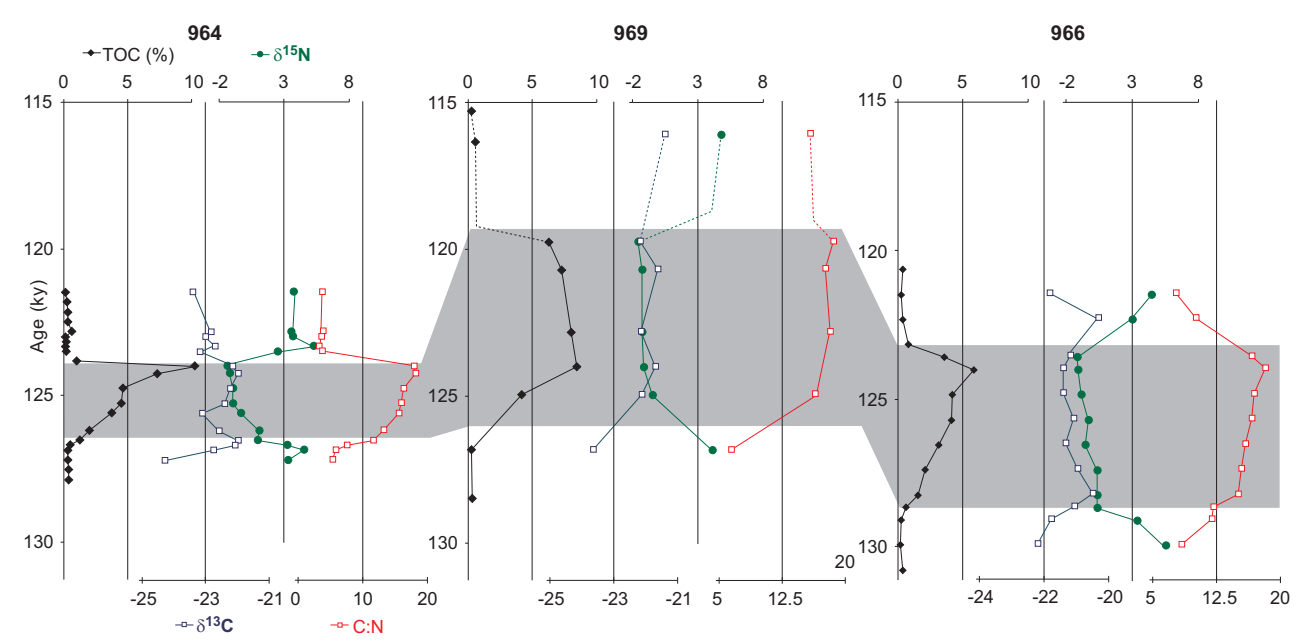

Fig. 8. TOC, C and N ratio, $\delta^{15} \mathrm{~N}, \delta^{13} \mathrm{C}$ for $\mathrm{S} 5$ at three studied sites. Shaded area corresponds to organic enriched sediments.

and/or diatom-hosted cyanobateria, (see review by Karl et al. (2002) and Kemp et al., (1999)), produce organic matter that is very low isotopically in nitrogen. This phenomenon would favor low $\delta^{15} \mathrm{~N}$ values, and at the same time, it would provide extra bioavailable nitrogen for other primary producers.

Nitrogen fixation is typically limited by $\mathrm{Fe}$, Mo and/or $\mathrm{P}$ availability (Karl et al., 2002). However, although river runoff would not be able to supply enough $\mathrm{N}$ to support the observed increase in productivity, it may have been capable of supplying oligoelements, such as $\mathrm{Fe}$, in quantities sufficient to induce higher productivity and $\mathrm{N}$-fixation by cyanobacteria and archaea. The extra freshwater input occurring across the basin (e.g., Gallego-Torres et al., 2010; Osborne et al., 2010) decreased salinity in the upper part of the water column. Lower salinity enhances Mo reactivity and availability, in the form of $\mathrm{MoO}_{4}^{-2}$, whereas $\mathrm{P}$ can readily be recycled by efficient scavenging in the water column (Karl et al., 2002) or reductive dissolution at the sedimentwater interface (e.g., Slomp et al., 2004). These multiple factors, along with an increase in sea surface temperature (e.g., Emeis et al., 2000b; Lourens et al., 1992), probably allowed the maintenance of blooms of $\mathrm{N}$-fixing organisms and associated biota.

The shift towards low $\delta^{15} \mathrm{~N}$ values during sapropel events is evident across the whole region and parallels or precedes the increase in export production indicated by $\mathrm{Ba}_{\mathrm{bio}}$ MARs (e.g., Dehairs et al., 1987; Gallego-Torres et al., 2007; Weldeab et al., 2003a). $\delta^{15} \mathrm{~N}$ values exhibit a progressive decrease from the onset of sapropel formation upwards, although not always parallel to $\mathrm{Ba} / \mathrm{Al}$ enrichments, and generally preceding the productivity maxima, indicating that maximum $\mathrm{N}$ fixation was followed by an increase in total export production. As a whole, low $\delta^{15} \mathrm{~N}$ values coincide well with increased organic carbon concentrations, in agreement with other sapropel studies (e.g., Calvert et al., 1992; Meyers and Arnaboldi, 2005; Milder et al., 1999; Struck et al., 2001). We thus infer that blooms of nitrogen-fixing biota were a central factor in creating the higher surface productivity that led to sapropel formation. 


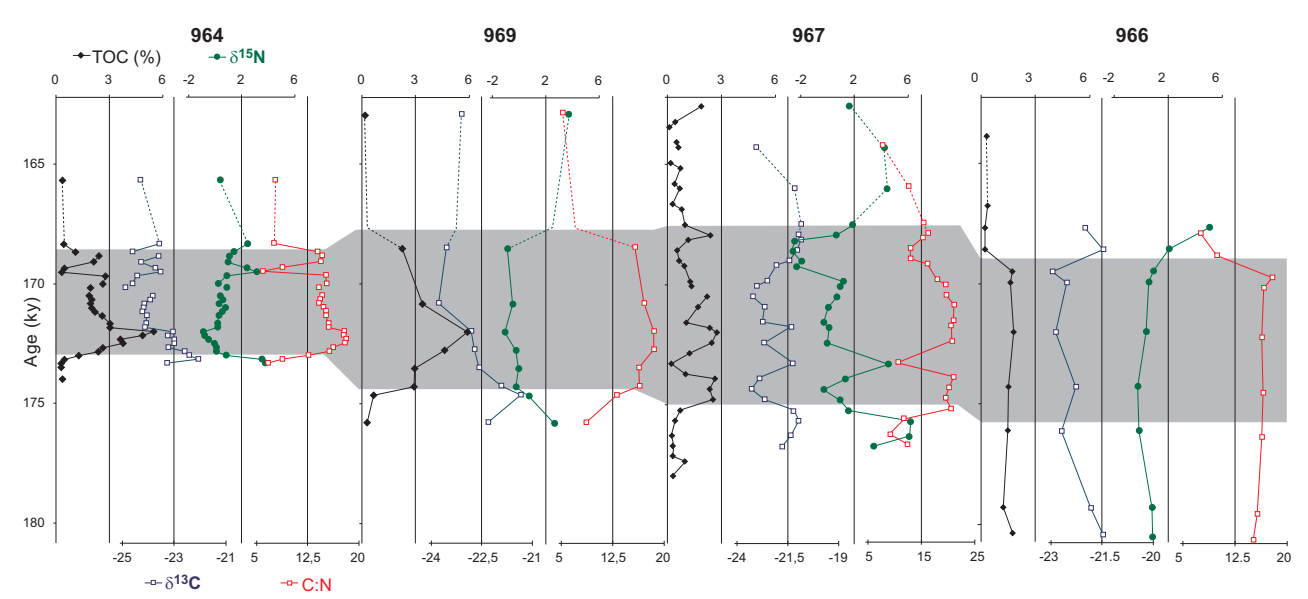

Fig. 9. TOC, $\mathrm{C}$ and $\mathrm{N}$ ratio, $\delta^{15} \mathrm{~N}, \delta^{13} \mathrm{C}$ for $\mathrm{S} 6$ at all studied sites. Shaded area corresponds to organic enriched sediments.

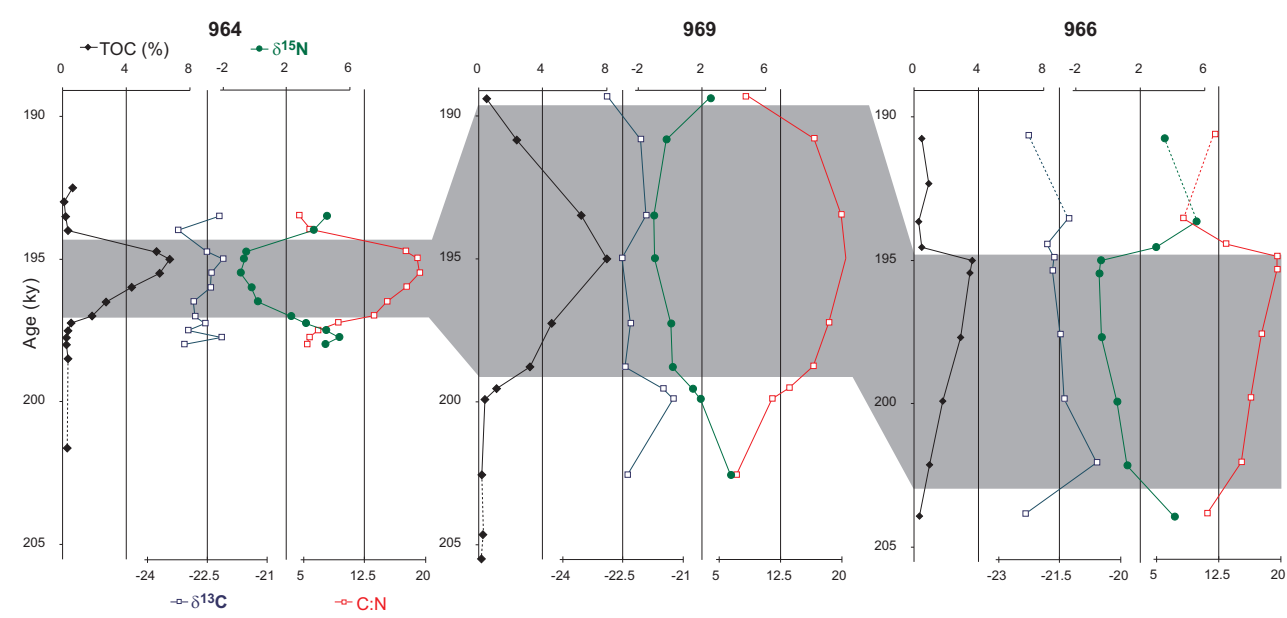

Fig. 10. TOC, $\mathrm{C}$ and $\mathrm{N}$ ratio, $\delta^{15} \mathrm{~N}, \delta^{13} \mathrm{C}$ for $\mathrm{S} 7$ at three studied sites. Shaded area corresponds to organic enriched sediments.

\subsubsection{Paleoproductivity patterns based on $\mathrm{Ba}$ and $\mathrm{C}_{\text {org }}$ concentration.}

Greater TOC concentration in sapropel sequences is consis-

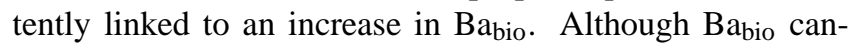
not be used to quantitatively determine export productivity (e.g., Averyt and Paytan, 2004; Gingele and Dahmke, 1994; Kasten et al., 2001; McManus et al., 1998, 1994), it has been widely and successfully applied as a relative indicator for enhanced marine productivity in the Mediterranean (e.g., Dehairs et al., 1987; Diester-Haass et al., 1998; Emeis et al., 2000a; Weldeab et al., 2003a). Furthermore, it has been shown that $\mathrm{Ba}$ content generally permits a better reconstruction of the duration of enhanced productivity and thus, true sapropel duration, than TOC, because barite is less sensitive to postdepositional oxidative destruction (e.g., Paytan and Kastner, 1996; Thomson et al., 1995). In Mediterranean sapropels, TOC destruction is evidenced by oxidation fronts in the form of high $\mathrm{Fe}$ and $\mathrm{Mn}$ concentrations above sapropel layers coinciding with low TOC concentra- tions, whereas high Ba concentrations typically remain preserved (e.g., Gallego-Torres et al., 2010, 2007; Larrasoaña et al., 2003b; Martínez-Ruiz et al., 2000; Thomson et al., 1995, 1999).

TOC and Babio MAR's are calculated assuming constant LSR's for each i-cycle (see Table 1). This assumption can conflict with the accepted "isochronous sapropel model" (e.g., de Lange et al., 2008; Rohling et al., 2006). However, assuming isochronous sapropel boundaries implies shifts in LSR's of up to $90 \%$ higher or up to $45 \%$ lower from background to sapropel sediments. Nijenhuis and de Lange (2000) proved the inconsistency of such shifts and suggested that MAR's should be calculated based on approximately linear sedimentation rate throughout each i-cycle. Owing to the necessity of selecting one hypothesis, constant LSR's were assumed.

Although the amounts of $\mathrm{Ba}_{\text {bio }}$ increase may vary among the layers, they always accompany the shift to higher TOCMAR at the base of the sapropels. As a whole, the Late Pleistocene sapropels, ranging in age from $81 \mathrm{ky}$ to $217 \mathrm{ky}$ 

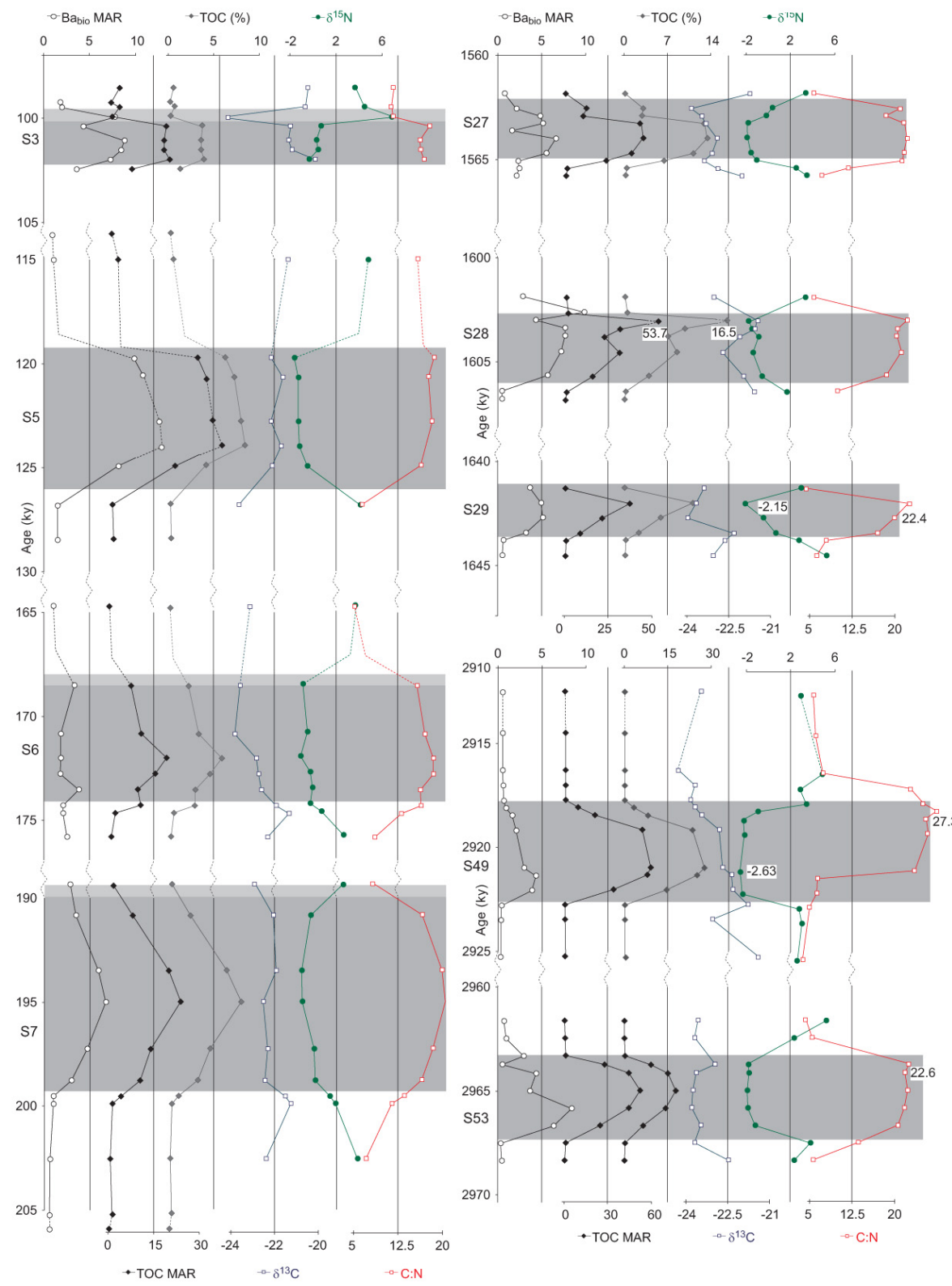

Fig. 11. Temporal evolution of the depositional conditions from Pliocene to Pleistocene, represented by TOC, Babio-MAR, $\mathrm{N}$ and $\mathrm{C}$ isotopic composition and C:N ratio on the Mediterranean Ridge (Site 969). For Holocene sapropel, see Figs. 2 and 6. Maximum off-scale values are numerically indicated in the graphs.

(see supplementary table) exhibit the highest export production levels of the studied sections, as represented by the highest Babio-MAR, although TOC and TOC-MAR's are higher during the Pliocene and Early Pleistocene. Thus, there is a poor relation between TOC accumulation and productivity $\left(\mathrm{Ba}_{\mathrm{bio}}\right.$ ), as presented on Fig. 13 (see also TOC/Ba $\mathrm{a}_{\text {bio }}$ on supplementary table), which is particularly evident comparing Pliocene and Late Pleistocene layers. Factors other than export productivity appear to have influenced sapropel formation during the Pliocene.
A disconnect between concentrations of $\mathrm{Ba}$ (unaltered signal for increased productivity) and TOC at the top of the Holocene S1 sapropel across the basin (different gray shadings, Fig. 2) and, to a lesser extent, in some Late Pleistocene sapropels, (Figs. 3 to 5; see also Gallego-Torres et al., 2010), indicates post-depositional oxidation of the organic matter at the top of the sapropel (e.g., Martínez-Ruiz et al., 2000; Thomson et al., 1995; Van Santvoort et al., 1996) probably due to relatively easier and faster reventilation of bottom waters. Opposite to this trend, the Early Pleistocene and Pliocene sapropels (Figs. 6 and 11) generally lack oxidation 


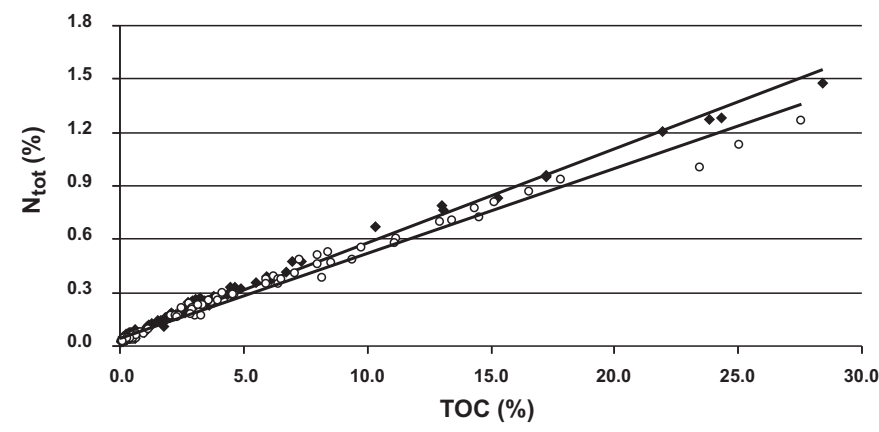

$$
\begin{array}{ll}
964 \bullet R^{2}=0.9921 & a=0.0531 \\
969 \circ R^{2}=0.982 & a=0.0476
\end{array}
$$

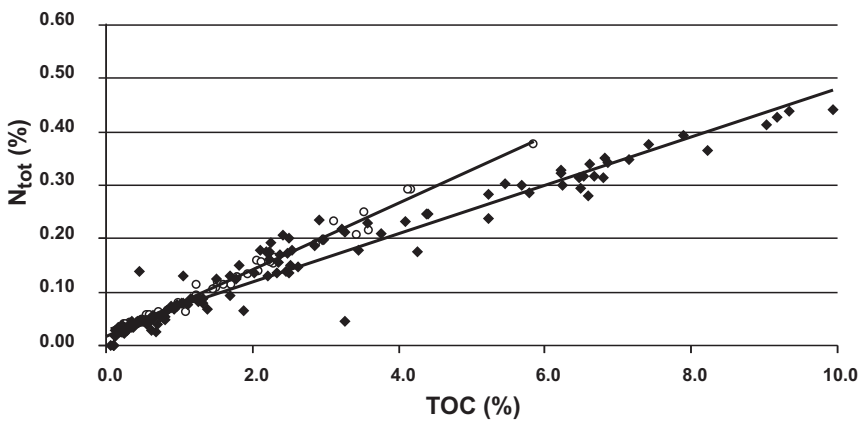

$966 \circ R^{2}=0.9898 \quad a=0.0623$

$967 \bullet R^{2}=0.9456 \quad a=0.0451$

Fig. 12. Total Nitrogen to TOC correlation. Very high correlation indicates that we may consider $N_{\text {tot }}=N_{\text {org }}$.

fronts. In fact, a reversed offset between $\mathrm{TOC}$ and $\mathrm{Ba} / \mathrm{Al}$ is evident in i-cycles 282 and 284 (S52 and S53, at Site 964 see Figs. 6 and 11). These sapropels originally developed as a result of an increase in export production recorded by Babio although productivity was less than in some of the Late Pleistocene sapropels. However TOC was preserved, reaching maximum concentrations continuing to accumulate after the return to normal surface productivity, probably due to the presence of anoxic bottom waters that favored its preservation. Anoxic conditions in the sediments could have remobilized $\mathrm{Ba}$ from the upper part of sapropels S53- (i-cycle 284) and S28 (i-cycle 156) (Fig. 11) (e.g., Arndt et al., 2009). The difference between the two paleoproductivity proxies suggests that deep-water circulation in the eastern Mediterranean during the middle Pliocene was slower than in the late Quaternary, leading to diminished deep-water reventilation.

From these lines of evidences we conclude that Pliocene and Early Pleistocene sapropel formation resulted from increased TOC accumulation as a combined consequence of enhanced productivity and better preservation despite relatively low sedimentation rates because of slower deep circulation and bottom-water oxygen depletion. In contrast lat Quaternary sapropels developed under higher sedimentation rates that mainly reflect higher productivity. Sluggish circulation during precessional minima also favored TOC accumulation, but as soon as productivity returned to normal low values deepwater oxygenation partially degraded organic matter in the upper part of sapropel layers.

\subsection{Sapropel expression across the eastern basin through time}

Our results reveal basin-wide patterns, temporal variations, and spatial differences in the history of sapropel deposition in the eastern Mediterranean Sea over the past $3 \mathrm{My}$. The general trend towards lighter $\mathrm{N}$-isotopic composition in the sapropel layers is clear but not particularly strong during the deposition of the Holocene S1 (i-cycle 2). The most plausible explanation for this weak signal is a minor increase in nitrogen-fixing cyanobacteria population and in overall marine productivity. The remaining Pleistocene and Pliocene sapropels show similar and essentially concordant trends across the basin: a progressive decrease of $\delta^{15} \mathrm{~N}$ values from the onset of sapropel formation upwards, frequently preceding $\mathrm{Ba} / \mathrm{Al}$ enrichment. At the oxidized top of the sapropel layers, loss of material does not permit us to assess whether $\mathrm{N}$-fixation continued during the whole high productivity phase.

The Ba-MARs during sapropel deposition are equivalent for deep water sites $(964,969$, and 967) whereas it is systematically lower at Site 966 . The same pattern is seen in TOC-MARs. Sites 966 and 967 are geographically proximate to each other, but their water depths are very different (926 m.b.s.l. vs. 2555 m.b.s.l). Export production, which is a surface ocean process, is expected to be similar at both sites. The difference in Ba MARs may be instead related to the degree of barite saturation and thus its preservation in the water column, which is depth dependent (e.g., Paytan and Griffith, 2007; Van Beek et al., 2006). In any case, for 

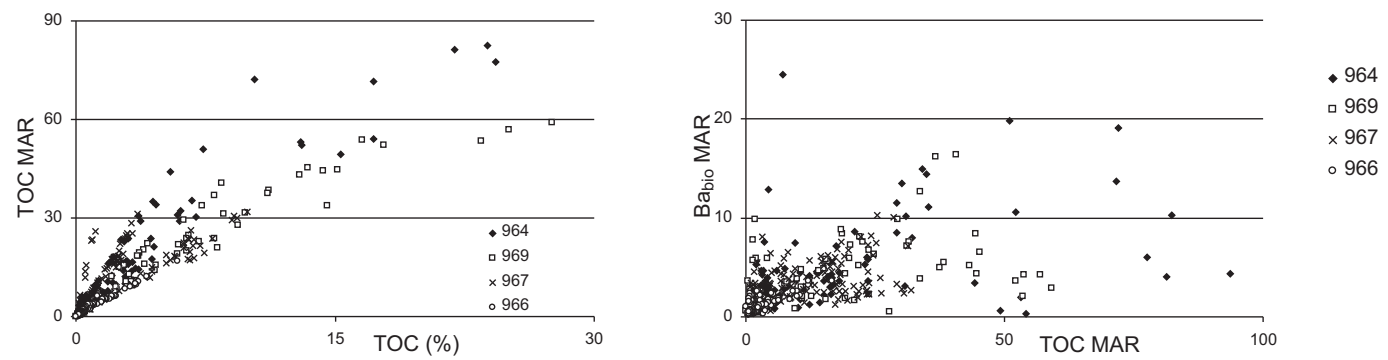

Fig. 13. Correlation between TOC vs. TOC-MAR and between TOC vs. Ba bio MAR for Sites 964, 969 and 967. Maximun TOC values do not correspond with highest $\mathrm{Ba}_{\mathrm{bio}} \mathrm{MAR}$ and viceversa.
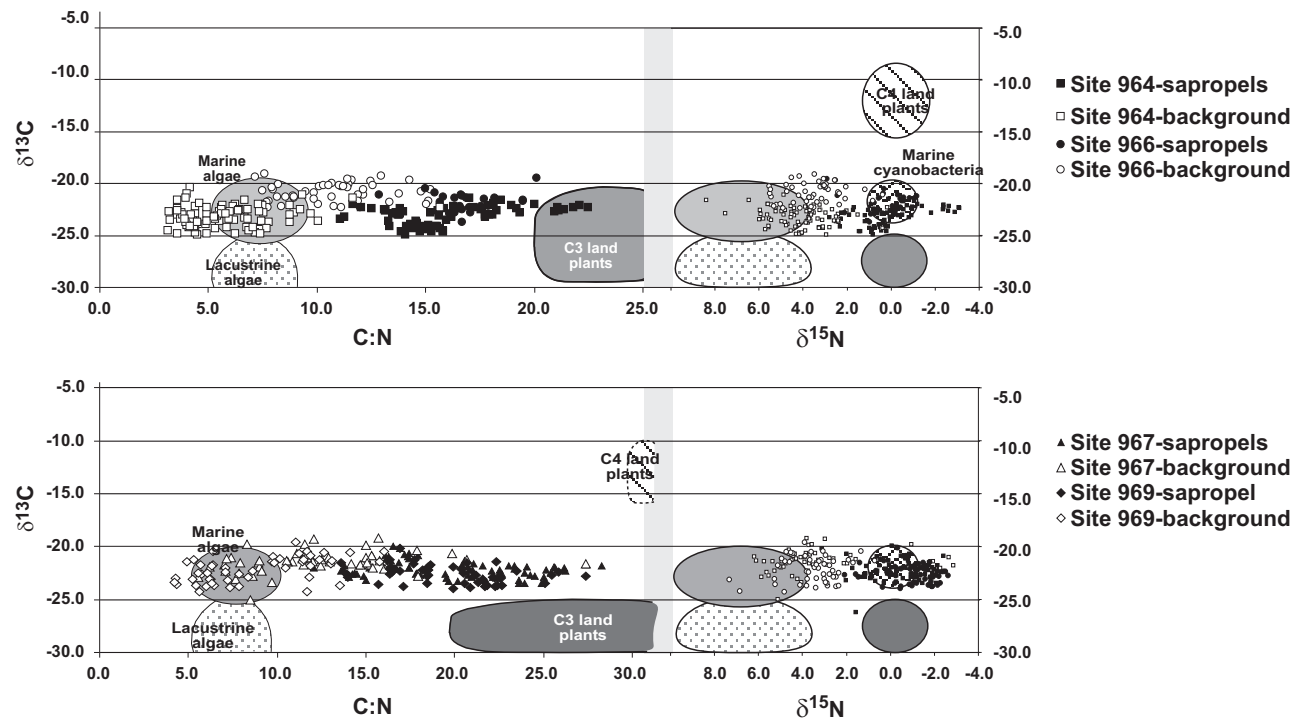

Fig. 14. Origin of the organic matter contained in the sampled sapropels as a function of $\delta^{15} \mathrm{~N}, \delta^{13} \mathrm{C}$ and $\mathrm{C}: \mathrm{N}$ ratios.

the same insolation cycle, the relatively shallow Site 966 exhibits the lowest TOC and Ba MARs of the four sites (Figs. 2 to 5). Therefore, it appears that greater water depth favors the burial and preservation of organic matter as proposed by Murat and Got (2000) and refined by de Lange et al. (2008), although it is not a factor influencing the primary process of sapropel formation itself. Sapropels on the top of Eratosthenes Seamount, although possessing lower TOC values, are characterized by all of the same features as those in the deep basin (increase in $\mathrm{Ba} / \mathrm{Al}$ and Ba-MAR, lower $\delta^{15} \mathrm{~N}$, higher TOC/TN). These proxies point toward sapropel formation being induced by basin-wide increased surface productivity, at least during the period between i-cycles 20 and 2, where we are able to compare similar layers across the basin.

In terms of time evolution of sapropel events, productivity maxima were reached during i-cycle 12 (S5), coinciding with maximum monsoon index (Kraal et al., 2010; Rossignol-Strick and Paterne, 1999). This pattern allows us to conclude that the same climatic factors (warm/wet periods during summer insolation maxima and enhanced monsoon activity) that triggered increased fluvial discharge and amplified nutrient input also favored the establishment of $\mathrm{N}$ fixing bacteria. This combination of factors ultimately induced sapropel formation.

From Figs. 3, 4 and 5, we observe that the duration of some sapropels (e.g., S5 to S7) appears to become longer from west to east. This pattern may indicate either a progressively shorter increased productivity event towards the west or an increase in sedimentation rates associated with sapropel forming conditions. A similar problem was addressed by Nijenhuis and de Lange (2000) and recently Katsouras et al. (2010) showed that S1 developed later in the Aegean Sea compared to the Lybian coast, by an offset of up to $0.9 \mathrm{ky}$. We do not have sufficient information (particularly, absolute dating) to resolve this issue. However, we are inclined to believe that this pattern results from differences in sedimentation rates inasmuch as the climate-driven surface paleoceanographic conditions that favored increased productivity were approximately stable and concordant across the basin. 


\subsection{Diagenesis}

The combination of TOC/TN ratios and $\delta^{13} \mathrm{C}$ and $\delta^{15} \mathrm{~N}$ values has been used to determine the origin of the organic matter in marine sediments (e.g., Bouloubassi et al., 1999; Meyers, 1997; Oldenburg et al., 2000; Rullkötter, 2000) by distinguishing between contributions from marine algae, marine cyanobacteria, lacustrine algae, and continental $\mathrm{C}_{3}-\mathrm{C}_{4}$ plants, as summarized by Meyers (1997). These parameters are plotted in Fig. 14 for the 35 analyzed sapropels. Holocene sediments plot close to the marine algae end member, with minor deviations coinciding with the highest TOC values. Pleistocene and Pliocene samples show a nearly bimodal distribution on the TOC/TN- $\delta{ }^{13} \mathrm{C}$ plot. The great majority of low TOC samples fall in the marine domain, the exception being a few samples from Site 967. Samples from within the sapropel shift towards higher C:N fields. In contrast, the $\delta^{15} \mathrm{~N}$ vs. $\delta^{13} \mathrm{C}$ plot systematically shows a marine algae composition for non-sapropel samples and a typical marine cyanobacteria composition for sapropel samples.

Although the TOC/TN vs. $\delta^{13} \mathrm{C}$ relation (Fig. 14) could be misinterpreted as resulting from an influence of continental input (i.e., $\mathrm{C}_{3}$ plants), the low $\delta^{15} \mathrm{~N}$ and $\delta^{15} \mathrm{~N}$ vs. $\delta^{13} \mathrm{C}$ plots suggest that the sapropels are dominated by marine organic matter, and independent evidence such as large values of the Rock-Eval Hydrogen Index (Bouloubassi et al., 1999; Emeis et al., 1996) and an abundance of marine biomarker molecules (Rinna et al., 2002) supports this interpretation. Nitrogen isotopic compositions are only slightly or not at all affected in preserved organic matter (Higgins et al., 2010), whereas under conditions of high surface productivity, the typical TOC/TN value of the exported organic matter is higher than the typical algal signal, partly due to selective remineralization of $\mathrm{N}$ and $\mathrm{N}$-rich molecules below the euphotic zone and/or at the sediment surface (e.g., Twichell et al., 2002). According to Freudenthal et al. (2001; see also Macko et al., 1994), TOC/TN ratios would increase when remineralization and preferential degradation of amino acids (isotopically higher) occurs along the water column. Similar results were obtained in sediment traps studies done by Van Mooy et al. (2002). Selective remineralization of amino acids simultaneously yields lower $\delta^{15} \mathrm{~N}$ values and higher TOC/TN values of deposited organic matter. The increase in TOC/TN can also partly be caused by denitrification under a suboxic environment (Karl et al., 2002) that is easily achieved under highly productive waters. These diagenetic changes support the conclusions made by Arnaboldi and Meyers (2006) on similar sapropel-bearing sediments in the eastern Mediterranean. It is evident that this increase in $\mathrm{TOC} / \mathrm{TN}$ ratio is more extreme during the Pliocene, in agreement with a highly restricted water column oxygenation for this period as postulated by Passier et al. (1999), Böttcher et al. (2003), Warning and Brumsack (2000), Larrasoaña et al., (2003a), and Weldeab et al. (2003a, b).
Lower $\mathrm{N}$-isotopic composition of organic matter mirrors the organic-rich levels, but it does not extend above oxidized sapropels to parallel the increase in productivity. Because nitrogen fixation seems to be crucial for sapropel formation, changes in export productivity ( $\mathrm{Ba}_{\mathrm{bio}}$ ) should run parallel to $\mathrm{N}$-fixing activity $\left(\delta^{15} \mathrm{~N}\right)$, inasmuch as both reflect primary production. However, the post burial burn-down oxidation may affect this signal. Specifically, oxidation of deposited organic matter preferentially consumes ${ }^{14} \mathrm{~N}$, so that the remaining organic matter in the sediment becomes enriched in ${ }^{15} \mathrm{~N}$ thus altering the $\delta^{15} \mathrm{~N}$ signal. Higgins et al. (2010) postulate that the $\mathrm{N}$ isotope signal is not affected by oxidation of decaying organic matter, although the resolution of their analyses is not high enough to discriminate oxidation fronts. However, if we accept their hypothesis, we may infer that the increase of $\delta^{15} \mathrm{~N}$ values immediately above sapropels $\mathrm{S} 1$ or S7 (light shading in Figs. 2 and 5) is due to better oxygenation of the overlying water column while high productivity conditions still prevailed.

\section{Summary and conclusions}

The remarkably lighter $\mathrm{N}$ isotopic compositions of the sapropel layers indicate periods of nitrogen fixation and thus, amplified cyanobacterial productivity (probably associated with bacterial mats) in the water column. Although $\mathrm{N}$-fixation is frequently associated with oligotrophic basins, in the case of Eastern Mediterranean sapropels it created a highly productive environment. This increase in $\mathrm{N}$-fixing biota and bacterial primary productivity increased export production and is reflected in major increases in TOC and Babio MARs. The change in mode of productivity is fueled by nutrient input (such as $\mathrm{P}, \mathrm{Fe}$ or $\mathrm{Mo}$ ), most likely through riverine discharge and by a warming environment with higher SST and lower SSS (Emeis and Weissert, 2009; Emeis et al., 2000b). These climatically driven productivity events affected the entire Eastern Mediterranean, independent of water depth. Differences in sapropel expression depend on water depth, related to winnowing, deep water circulation and/or $\mathrm{SO}_{4}^{-2}$ saturation.

Our results allow us to distinguish between the importance of organic matter production and its preservation in forming the sapropel layers. TOC-MAR and Babio MAR do not show a direct correlation with $\mathrm{C}_{\text {org }}$ concentration and $\mathrm{Ba} / \mathrm{Al}$ ratio, respectively. Some Late Pleistocene sapropels, such as S5 (i-cycle 12) have lower TOC concentrations but higher TOC and $\mathrm{Ba}_{\text {bio }}$ MAR's than older equivalents, indicating that both marine productivity and detrital sedimentation dramatically increased during the Late Pleistocene. Opposite to this trend, Early Pleistocene and Pliocene sapropels accumulated under markedly lower sedimentation rates and therefore exhibit higher Ba concentrations but lower MARs than Late Pleistocene equivalents. In other words, greater productivity does not directly result in higher TOC accumulation (Fig. 13). The Pliocene and Early Pleistocene relatively smaller increases 
in productivity correspond to limited water mass circulation than in Late Pleistocene times; water mass circulation may have even reversed (estuarine circulation, e.g., Böttcher et al., 2003; Wehausen and Brumsack, 1999) favouring bottom water stagnation. This interpretation implies that organic carbon concentration in these layers is equally influenced by both preservation and productivity. Variations in deep water circulation are also responsible for different diagenetic imprints on TOC, TOC/TN ratio and $\delta^{15} \mathrm{~N}$ signals.

Humidity maxima also contribute to the intensity of productivity increase by magnifying fluvial nutrient input into the basin. Higher humidity signifies stronger river runoff, higher nutrient supply from the continent and, at the same time, increased detrital input that would increase sedimentation rates. If we consider the increase in African derived nutrient input as climatically controlled (in turn defined by insolation cycles), the maximum increase in fluvial input should correspond to i-cycles 12 to 20 , which show the greatest maximum summer insolation $\left(500\right.$ to $520 \mathrm{~W} / \mathrm{m}^{2}$ ) according to Emeis et al. (1996) and Lourens et al. (2004). Sampled sapropels from i-cycles 152 to 182 correspond to insolation peaks that remain around $500 \mathrm{~W} \mathrm{~m}^{-2}$ (Larrasoaña et al., 2003a) or below, for i-cycles 270 to 286 . Thus, detrital and nutrient input would be the highest at maximum insolation (i.e., Late Pleistocene). This prediction is supported by our results that reveal relatively low TOC concentration compared to older equivalents and, at the same time, the very high TOC and $\mathrm{Ba}_{\mathrm{bio}}$-MARs found at all four sites, for example during i-cycle 12 . The relative sizes of the increases in sedimentation rates and productivity rates are evidently related to the amplitudes of the precessional insolation and humidity maxima (monsoon index).

A remarkable increase in TOC/TN ratios, related to denitrification processes, suggests intense oxygen consumption below the euphotic zone. The $\delta^{15} \mathrm{~N}$ signal, although mostly representing a primary signal, might be shifted to somewhat larger values by diagenetic oxidation that is evident in diminished TOC concentrations at the tops of sapropel layers because of oxidative burndown.

\section{Supplementary material related to this article is available online at: http://www.biogeosciences. net/8/415/2011/bg-8-415-2011-supplement.pdf.}

Acknowledgements. We are grateful to the Ocean Drilling Program for providing us with the samples used in this study as well as to the ODP Core Repository (Bremen, Germany) for assistance with sampling. Major and trace elements analyses were performed at the "Centro de Intrumentacion Cientifica" (University of Granada). TC-TOC measurements were done at the Stable Isotope Lab (Green Earth Science Building, Stanford University) and Bremen University (MARUM). Stable Isotope analyses were done at Stable Isotope Lab (Green Earth Science Building, Stanford University. We also acknowledge the collaboration of Dr. Oscar Romero in TC-TOC analysis at Bremen University. We thank R. Capozzi,
K. C. Emeis and one anonymous reviewer, for their comments that were very helpful in improving this manuscript, as well as A. Shemesh for his Editor labour. This work was financed by Projects MARM 200800050084447, MICINN CGL2009-07603, Junta de Andalucía RNM-5212 and Research Group RNM 179 (Junta de Andalucía), We also thank Project CSD2006-00041 Topoberia. We would also like to thank the "Plan Propio de Investigación (UGR)" for financial support (postdoctoral fellowship D. Gallego-Torres).

Edited by: A. Shemesh

\section{References}

Altabet, M. A. and Francois, R.: Sedimentary nitrogen isotopic ratio as a recorder for surface ocean nitrate utilization, Global Biogeochem. Cy., 8, 103-116, 1994.

Altabet, M. A., Murray, D. W., and Prell, W. L.: Climatically linked oscillations in Arabian Sea denitrification over the past 1 M.y.: Implications for the marine N cycle, Paleoceanography, 14, 723743, 1999.

Arnaboldi, M. and Meyers, P. A.: Patterns of organic carbon and nitrogen isotopic compositions of latest Pliocene sapropels from six locations across the Mediterranean Sea, Palaeogeogr., Palaeocl., 235, 149-167, 2006.

Arndt, S., Hetzel, A., and Brumsack, H. J.: Evolution of organic matter degradation in Cretaceous black shales inferred from authigenic barite: A reaction-transport model, Geochim. Cosmochim. Ac., 73, 2000-2022, 2009.

Astraldi, A., Conversano, F., Civitarese, G., Gasparini, G. P., d'Alcala, M. R., and Vetrano, A.: Water mass properties and chemical signatures in the central Mediterranean region, J. Mar. Syst., 33, 155-177, 2002.

Averyt, K. B. and Paytan, A.: A comparison of multiple proxies for export production in Equatorial Pacific, Paleoceanography, 19, 1-14, 2004.

Bea, F.: Residence of REE, Y, Th and U in granites and crustal protoliths: Implications for the chemistry of crustal melts, J. Petrol., 37, 521-532, 1996.

Bethoux, J. P.: Oxygen consumption, new production, vertical advection and environmental evolution in the Mediterranean Sea, Deep Sea Res., 36, 769-781, 1989.

Böttcher, M. E., Rinna, J., Warning, B., Wehausen, R., Howell, M. W., Schnetger, B., Stein, R., Brumsack, H.-J., and Rullkotter, J.: Geochemistry of sediments from the connection between the Western and the Eastern Mediterranean Sea (Strait of Sicily, ODP Site 963), Palaeogeogr. Palaeocl., 190, 165-194, 2003.

Bouloubassi, I., Rullkotter, J., and Meyers, P. A.: Origin and transformation of organic matter in Pliocene-Pleistocene mediterranean sapropels: Organic geochemical evidence reviewed, Mar. Geol., 153, 177-197, 1999.

Calvert, S. E. and Pedersen, T. F.: Geochemistry of recent oxic and anoxic marine sediments: Implications for the geological record, Mar. Geol., 113, 67-88, 1993.

Calvert, S. E., Bustin, R. M., and Ingall, E. D.: Influence of water column anoxia and sediment supply on the burial and preservation of organic carbon in marine shales, Geochim. Cosmochim. Ac., 60, 1577-1593, 1996. 
Calvert, S. E.: Beware intercepts: Interpreting compositional ratios in multi-component sediments and sedimentary rocks, Org. Geochem., 35, 981-987, 2004.

Calvert, S. E., Nielse, B., and Fontugne, M. R.: Evidence from nitrogen isotope ratios for enhanced productivity during formation of Eastern Mediterranean sapropels, Nature, 359, 223-235, 1992.

Cane, T., Rohling, E. J., Kemp, A. E. S., Cooke, S., and Pearce, R. B.: High-resolution stratigraphic framework for Mediterranean sapropel S5: Defining temporal relationships between records of Eemian climate variability, Palaeogeogr. Palaeocl., 183, 87-101, 2002.

Capotondi, L., Principato, M. S., Morigi, C., Sangiorgi, F., Maffioli, P., Giunta, S., Negri, A., and Corselli, C.: Foraminiferal variations and stratigraphic implications to the deposition of sapropel S5 in the Eastern Mediterranean, Palaeogeogr. Palaeocl., 235, 48-65, doi:10.1016/j.palaeo.2005.09.023, 2006.

Casford, J. S. L., Rohling, E. J., Abu-Zied, R. H., Fontanier, C., Jorissen, F. J., Leng, M. J., Schmiedl, G., and Thomson, J.: A dynamic concept for Eastern Mediterranean circulation and oxygenation during sapropel formation, Palaeogeogr. Palaeocl., 190, 103-119, 2003.

de Lange, G. J.: Distribution of exchangeable, fixed, organic and total nitrogen in interbedded turbiditic/pelagic sediments of the Madeira abyssal plain, Eastern North Atlantic, Mar. Geol., 109, 95-114, 1992.

de Lange, G. J., Thomson, J., Reitz, A., Slomp, C. P., Principato, M. S., Erba, E., and Corselli, C.: Synchronous basin-wide formation and redox-controlled preservation of a Mediterranean sapropel, Nat. Geosci., 1, 606-610, doi:10.1038/ngeo283, 2008.

Dehairs, F., Lambert, C. E., Chesselet, R., and Risler, N.: The biological production of marine suspended barite and the barium cycle in the Western Mediterranean Sea, Biogeochemistry, 4, 19139, 1987.

Diester-Haass, L., Robert, C., and Chamley, H.: Paleoproductivity and climate variations during sapropel deposition in the Eastern Mediterranean Sea, in: Proceedings of Ocean Drilling Program, Scientific Results, edited by: Robertson, A. H. F., Emeis, K.-C., Richter, C., and Camerlenghi, A., College Station, Texas, 227248, 1998.

Dymond, J., Suess, E., and Lyle, M.: Barium in deep-sea sediment: A geochemical proxy for paleoproductivity, Paleoceanography, 163-181, 1992.

Dymond, J. and Collier, R.: Particulate barium fluxes and their relationships to biological productivity, Deep-Sea Res. Pt. II, 43, 1281-1308, 1996.

Emeis, K.-C., Sakamoto, T., Wehausen, R., and Brumsack, H.-J.: The sapropel record of the Eastern Mediterranean Sea - results of Ocean Drilling Program Leg 160, Palaeogeogr. Palaeocl., 158, 371-395, 2000a.

Emeis, K.-C., Struck, U., Schulz, H.-M., Rosenberg, R., Bernasconi, S., Erlenkeuser, H., Sakamoto, T., and MartinezRuiz, F.: Temperature and salinity variations of Mediterranean Sea surface waters over the last 16,000 years from records of planktonic stable oxygen isotopes and alkenone unsaturation ratios, Palaeogeogr., Palaeocl., 158, 259-280, 2000b.

Emeis, K. C., Robertson, A. H. F., and Ritcher, C. E. A.: Proceedings of the Ocean Drilling Program, Initial Reports, Vol. 160, College Station, Texas, 1996.
Emeis, K. C., Schulz, H., Struck, U., Rossignol-Strick, M., Erlenkeuser, H., Howell, M. W., Kroon, D., Mackensen, A., Ishizuka, S., Oba, T., Sakamoto, T., and Koizumi, I.: Eastern Mediterranean surface water temperatures and $\delta^{18} \mathrm{O}$ composition during deposition of sapropels in the late Quaternary, Paleoceanography, 18, 1005, doi:10.1029/2000pa000617, 2003.

Emeis, K. C. and Weissert, H.: Tethyan-Mediterranean organic carbon-rich sediments from Mesozoic black shales to sapropels, Sedimentology, 56, 247-266, 2009.

Filippelli, G. M., Sierro, F. J., Flores, J. A., Vazquez, A., Utrilla, R., Perez-Folgado, M., and Latimer, J. C.: A sediment-nutrientoxygen feedback responsible for productivity variations in late Miocene sapropel sequences of the Western Mediterranean, Palaeogeogr. Palaeocl., 190, 335-348, 2003.

Freudenthal, T., Wagner, T., Wenzhofer, F., Zabel, M., and Wefer, G.: Early diagenesis of organic matter from sediments of the Eastern Subtropical Atlantic: Evidence from stable nitrogen and carbon isotopes, Geochim. Cosmochim. Ac., 65, 1795-1808, 2001.

Gallego-Torres, D., Martinez-Ruiz, F., Paytan, A., Jimenez-Espejo, F. J., and Ortega-Huertas, M.: Pliocene-Holocene evolution of depositional conditions in the Eastern Mediterranean: Role of anoxia vs. Productivity at time of sapropel deposition, Palaeogeogr. Palaeocl., 246, 424-439, 2007.

Gallego-Torres, D., Martinez-Ruiz, F., de Lange, G., JimenezEspejo, F. J., and Ortega-Huertas, M.: Trace-elemental derived paleoceanographic and paleoclimatic conditions for Pleistocene Eastern Mediterranean sapropels, Palaeogeogr. Palaeocl., 293, 76-89, 2010.

Gingele, F. and Dahmke, A.: Discrete barite particles and barium as tracers of paleoproductivity in South Atlantic sediments, Paleoceanography, 9, 151-168, 1994.

Higgins, M. B., Robinson, R. S., Carter, S. J., and Pearson, A.: Evidence from chlorin nitrogen isotopes for alternating nutrient regimes in the Eastern Mediterranean Sea, Earth Planet. Sci. Lett., 290, 102-107, 2010.

Hilgen, F. J.: Astronomical calibration of Gauss to Matuyama sapropels in the Mediterranean and implication for the geomagnetic polarity time scale, Earth Planet. Sci. Lett., 104, 226-244, 1991.

Jenkins, J. A. and Williams, D. F.: Nile water as a cause of Eastern Mediterranean sapropel formation: Evidence for and against, Mar. Micropaleontol., 8, 521-534, 1984.

Karl, D., Michaels, A., Bergman, B., Capone, D., Carpenter, E., Letelier, R., Lipschultz, F., Paerl, H., Sigman, D., and Stal, L.: Dinitrogen fixation in the world's oceans, Biogeochemistry, 57, 47-98, 2002.

Kasten, S., Haese, R. R., Zabel, M., Ruhlemann, C., and Schulz, H. D.: Barium peaks at glacial terminations in sediments of the Equatorial Atlantic ocean-relicts of deglacial productivity pulses?, Chem. Geol., 175, 635-651, 2001.

Katsouras, G., Gogou, A., Bouloubassi, I., Emeis, K. C., Triantaphyllou, M., Roussakis, G., and Lykousis, V.: Organic carbon distribution and isotopic composition in three records from the Eastern Mediterranean sea during the Holocene, Organic Geochem., 41(9), 935-939, 2010.

Kemp, A. E. S., Pearce, R. B., Koizumi, I., Pike, J., and Rance, S. $\mathrm{J} .:$ The role of mat-forming diatoms in the formation of Mediterranean sapropels, Nature, 398, 57-60, 1999. 
Kidd, R. B., Cita, M. B., and Ryan, W. B. F.: Stratigraphy of Eastern Mediterranean sapropel sequences recovered during Leg 42A and their paleoenvironmental significance, in: Initial report DSDP, 421-443, 1978.

Knicker, H. and Hatcher, P. G.: Sequestration of organic nitrogen in the sapropel from mangrove lake, Bermuda, Organic Geochem., 32, 733-744, 2001.

Kraal, P., Slomp, C. P., and de Lange, G. J.: Sedimentary organic carbon to phosphorus ratios as a redox proxy in Quaternary records from the Mediterranean, Chem. Geol., 277, 167$177,2010$.

Krom, M. D., Herut, B., and Mantoura, R. F. C.: Nutrient budget for the Eastern Mediterranean: Implications for phosphorus limitation, Limnol. Oceanogr., 49, 1582-1592, 2004.

Kuypers, M. M. M., van Breugel, Y., Schouten, S., Erba, E., and Damste, J. S. S.: N-2-fixing cyanobacteria supplied nutrient $\mathrm{n}$ for Cretaceous oceanic anoxic events, Geology, 32, 853-856, 2004.

Larrasoaña, J. C., Roberts, A. P., Rohling, E. J., Winklhofer, M., and Wehausen, R.: Three million years of monsoon variability over the Northern Sahara, Clim. Dynam., 21, 689-698, 2003a.

Larrasoaña, J. C., Roberts, A. P., Stoner, J. S., Richter, C., and Wehausen, R.: A new proxy for bottom-water ventilation in the Eastern Mediterranean based on diagenetically controlled magnetic properties of sapropel-bearing sediments, Palaeogeogr. Palaeocl., 190, 221-242, 2003b.

Lehmann, M. F., Bernasconi, S. M., Barbieri, A., and McKenzie, J. A.: Preservation of organic matter and alteration of its carbon and nitrogen isotope composition during simulated and in situ early sedimentary diagenesis, Geochim. Cosmochim. Ac., 66, 35733584, 2002.

Lourens, L. J., Hilgen, F. J., Gudjonsson, L., and Zachariasse, W. J.: Late Pliocene to early Pleistocene astronomically forced sea surface productivity and temperature variations in the Mediterranean, Mar. Micropaleontol., 19, 49-78, 1992.

Lourens, L. J.: Revised tuning of Ocean Drilling Program Site 964 and KC01B (Mediterranean) and implications for the $\delta^{18} \mathrm{O}$, tephra, calcareous nannofossil, and geomagnetic reversal chronologies of the past $1.1 \mathrm{Myr}$, Paleoceanography, 19, 1-20, doi:10.1029/2003PA000997, 2004.

Macko, S. A., Engel, M. H., and Qian, Y. R.: Early diagenesis and organic-matter preservation - a molecular stable carbon-isotope perspective, Chem. Geol., 114, 365-379, 1994.

Mangini, A. and Schlosser, P.: The formation of Eastern Mediterranean sapropels, Mar. Geol., 72, 115-124, 1986.

Mara, P., Mihalopoulos, N., Gogou, A., Daehnke, K., Schlarbaum, T., Emeis, K. C., and Krom, M.: Isotopic composition of nitrate in wet and dry atmospheric deposition on Crete in the Eastern Mediterranean Sea, Global Biogeochemical Cy., 23, doi:10.1029/2008gb003395, 2009.

Martínez-Ruiz, F., Paytan, A., Kastner, M., Gonzalez-Donoso, J. M., Linares, D., Bernasconi, S. M., and Jimenez-Espejo, F. J.: A comparative study of the geochemical and mineralogical characteristics of the S1 sapropel in the Western and Eastern Mediterranean, Palaeogeogr. Palaeocl., 190, 23-37, 2003.

Martínez-Ruiz, F., Kastner, M., Paytan, A., Ortega-Huertas, M., and Bernasconi, S. M.: Geochemical evidence for enhanced productivity during S1 sapropel deposition in the Eastern Mediterranean, Paleoceanography, 15, 200-209, 2000.

McManus, J., Berelson, W. M., Klinkhammer, G. P., Kilgore, T. E., and Hammond, D. E.: Remobilization of barium in continentalmargin sediments, Geochim. Cosmochim. Ac., 58, 4899-4907, 1994.

McManus, J., Berelson, W. M., Klinkhammer, G. P., Johnson, K. S., Coale, K. H., Anderson, R. F., Kumar, N., Burdige, D. J., Hammond, D. E., Brumsack, H. J., McCorkle, D. C., and Rushdi, A.: Geochemistry of barium in marine sediments: Implications for its use as a paleoproxy, Geochim. Cosmochim. Ac., 62, 34533473, 1998.

Menzel, D., van Bergen, P. F., Schouten, S., and Sinninghe Damste, J. S.: Reconstruction of changes in export productivity during Pliocene sapropel deposition: A biomarker approach, Palaeogeogr. Palaeocl., 190, 273-287, 2003.

Meyers, P. A.: Organic geochemical proxies of paleoceanographic, paleolimnologic, and paleoclimatic processes, Organic Geochem., 27, 213-250, 1997.

Meyers, P. A. and Arnaboldi, M.: Trans-Mediterranean comparison of geochemical paleoproductivity proxies in a midPleistocene interrupted sapropel, Palaeogeogr. Palaeocl., 222, 313-328, 2005.

Meyers, P. A. and Bernasconi, S. M.: Carbon and nitrogen isotope excursions in mid-Pleistocene sapropels from the Tyrrhenian basin: Evidence for climate-induced increases in microbial primary production, Mar. Geol., 220, 41-58, 2005.

Meyers, P. A. and Arnaboldi, M.: Paleoceanographic implications of nitrogen and organic carbon isotopic excursions in mid-Pleistocene sapropels from the Tyrrhenian and Levantine basins, Mediterranean Sea, Palaeogeography, Palaeoclimatology, Palaeoecology, 266, 112-118, 2008.

Milder, J. C., Montoya, J. P., and Altabet, M. A.: Carbon and nitrogen stable isotope ratios at sites 969 and 974: Interpreting spatial gradients in sapropel properties, in: ODP Scientific Results, Vol. 161, edited by: Zahn, R., Comas, M. C., and Klaus, A., 401-411, 1999.

Mucciarone, D. A.: Standard operating procedure, http://pangea.stanford.edu/research/isotope/dam/pdf/ Stanford_SIL_Online_manual.pdf (last access: 2010), 2003.

Murat, A., and Got, H.: Organic carbon variations of the Eastern Mediterranean Holocene sapropel: A key for understanding formation processes, Palaeogeogr. Palaeocl., 158, 241-257, 2000.

Nakatsuka, T., Handa, N., Harada, N., Sugimoto, T., and Imaizumi, S.: Origin and decomposition of sinking particulate organic matter in the deep water column inferred from the vertical distributions of its $\delta^{15} \mathrm{~N}, \delta^{13} \mathrm{C}$ and $\delta^{14} \mathrm{C}$, Deep Sea Res. Pt. I, 44, 1957-1979, 1997.

Nijenhuis, I. A. and de Lange, G. J.: Geochemical constraints on Pliocene sapropel formation in the Eastern Mediterranean, Mar. Geol., 163, 41-63, 2000.

Oldenburg, T. B. P., Rullkotter, J., Böttcher, M. E., and Nissenbaum, A.: Molecular and isotopic characterization of organic matter in recent and sub-recent sediments from the Dead Sea, Organic Geochem., 31, 251-265, 2000.

Osborne, A. H., Marino, G., Vance, D., and Rohling, E. J.: Eastern Mediterranean surface water $\mathrm{Nd}$ during Eemian sapropel S5: Monitoring northerly (mid-latitude) versus southerly (subtropical) freshwater contributions, Quaternary Sci. Rev., 29, 2473-2483, 2010.

Pantoja, S., Repeta, D. J., Sachs, J. P., and Sigman, D. M.: Stable isotope constraints on the nitrogen cycle of the Mediterranean 
Sea water column, Deep-Sea Res. Pt. I, 49, 1609-1621, 2002.

Passier, H. F., Middelburg, J. J., van Os, B. J. H., and de Lange, G. J.: Diagenetic pyritisation under Eastern Mediterranean sapropels caused by downward sulphide diffusion, Geochim. Cosmochim. Ac., 60, 751-763, 1996.

Passier, H. F., Middelburg, J. J., de Lange, G. J., and Böttcher, M. E.: Modes of sapropel formation in the Eastern Mediterranean: Some constraints based on pyrite properties, Mar. Geol., 153, 199-219, 1999.

Paytan, A. and Kastner, M.: Benthic Ba fluxes in the central Equatorial Pacific, implications for the oceanic Ba cycle, Earth Planet. Sci. Lett., 142, 439-450, 1996.

Paytan, A. and Griffith, E. M.: Marine barite: Recorder of variations in ocean export productivity, Deep-Sea Res. Pt. II, 54, 687-705, 2007.

Pedersen, T. F. and Calvert, S. E.: Anoxia vs. Productivity: What controls the formation of organic-carbon-rich sediments and sedimentary rocks?, The American Association of Petroleum Geologists Bulletin, 74, 454-466, 1990.

Peters, K. E., Sweeney, R. E., and Kaplan, I. R.: Correlation of carbon and nitrogen stable isotope ratios in sedimentary organic matter, Limnol. Oceanogr., 23 598-604, 1978.

Rinna, J., Warning, B., Meyers, P. A., Brumsack, H. J., and Rullkotter, J.: Combined organic and inorganic geochemical reconstruction of paleodepositional conditions of a Pliocene sapropel from the Eastern Mediterranean Sea, Geochim. Cosmochim. Ac., 66, 1969-1986, 2002.

Rohling, E. J. and Hilgen, F. J.: The Eastern Eediterranean climate at times of sapropel formation - a review, Geol. Mijnbouw, 70, 253-264, 1991.

Rohling, E. J., Hopmans, E. C., and Damste, J. S. S.: Water column dynamics during the last interglacial anoxic event in the Mediterranean (sapropel S5), Paleoceanography, 21, Pa2018, doi:10.1029/2005pa001237, 2006.

Rossignol-Strick, M.: Mediterranean Quaternary sapropels, an immediate response of the African monsoon to variation of insolation, Palaeogeogr. Palaeocl., 49, 237-263, 1985.

Rossignol-Strick, M. and Paterne, M.: A synthetic pollen record of the Eastern Mediterranean sapropels of the last $1 \mathrm{Ma}$ : Implications for the time-scale and formation of sapropels, Mar. Geol., 153, 221-237, 1999.

Rullkötter, J.: Organic matter: The driving force for early diagenesis, in: Marine geochemistry, edited by: Schulz, H. D. a. Z., M., Springer, 129-172, 2000.

Sachs, J. P. and Repeta, D. J.: Oligotrophy and nitrogen fixation during Eastern Mediterranean sapropel events, Science, 286, 24852488, 1999.

Sakamoto, T., Janecek, T., and Emeis, K. C.: Continuous sedimentary sequences from the Eastern Mediterranean Sea: Composite depth sections, Proceedings of the Ocean Drilling Program: Scientific Results, 160, 37-60, 1998.

Schubert, C. J. and Calvert, S. E.: Nitrogen and carbon isotopic composition of marine and terrestrial organic matter in Arctic Ocean sediments: Implications for nutrient utilization and organic matter composition, Deep-Sea Res. Pt. I, 48, 789-810, 2001.

Slomp, C. P., Thomson, J., and de Lange, G. J.: Controls on phosphorus regeneration and burial during formation of Eastern Mediterranean sapropels, Mar. Geol., 203, 141-159, 2004.
Struck, U., Emeis, K.-C., Voss, M., Krom, M. D., and Rau, G. H.: Biological productivity during sapropel S5 formation in the Eastern Mediterranean Sea: Evidence from stable isotopes of nitrogen and carbon, Geochim. Cosmochim. Ac., 65, 3249-3266, 2001.

Tanaka, T., Thingstad, T. F., Christaki, U., Colombet, J., CornetBarthaux, V., Courties, C., Grattepanche, J.-D., Lagaria, A., Nedoma, J., Oriol, L., Psarra, S., Pujo-Pay, M., and Van Wambeke, F.: N-limited or $\mathrm{N}$ and $\mathrm{P}$ co-limited indications in the surface waters of three Mediterranean basins, Biogeosciences Discuss., 7, 8143-8176, doi:10.5194/bgd-7-8143-2010, 2010.

Thomson, J., Higgs, N. C., Wilson, T. R. S., Croudace, I. W., de Lange, G. J., and Van Santvoort, P. J. M.: Redistribution and geochemical behaviour of redox-sensitive elements around S1, the most recent Eastern Mediterranean sapropel, Geochim. Cosmochim. Ac., 59, 3487-3501, 1995.

Thomson, J., Mercone, D., de Lange, G. J., and Van Santvoort, P. J. M.: Review of recent advances in the interpretation of Eastern Mediterranean sapropel S1 from geochemical evidence, Mar. Geol., 153, 77-89, 1999.

Twichell, S. C., Meyers, P. A., and Diester-Haass, L.: Significance of high $\mathrm{C} / \mathrm{N}$ ratios in organic-carbon-rich Neogene sediments under the Benguela current upwelling system, Organic Geochem., 33, 715-722, 2002.

Van Beek, P., Francois, R., Conte, M., Reyss, J.-L., Souhaut, M., and Charette, M.: ${ }^{228} \mathrm{Ra} /{ }^{226} \mathrm{Ra}$ and ${ }^{226} \mathrm{Ra} / \mathrm{Ba}$ ratios to track barite formation and transport in the water column, Geochim. Cosmochim. Ac., 71, 71-86, 2006.

Van Mooy, B. A. S., Keil, R. G., and Devol, A. H.: Impact of suboxia on sinking particulate organic carbon: Enhanced carbon flux and preferential degradation of amino acids via denitrification, Geochim. Cosmochim. Ac., 66, 457-465, 2002.

Van Santvoort, P. J. M., de Lange, G. J., Thomson, J., Cussen, H., Wilson, T. R. S., Krom, M. D., and Strohle, K.: Active postdepositional oxidation of the most recent sapropel (S1) in sediments of the Eastern Mediterranean sea, Geochim. Cosmochim. Ac., 60, 4007-4024, 1996.

Voss, M., Altabet, M. A., and Bodungen, B. V.: $\delta^{15} \mathrm{~N}$ in sedimenting particles as indicator of euphotic-zone processes, Deep Sea Res. Pt. I, 43, 33-47, 1996.

Warning, B. and Brumsack, H.-J.: Trace metal signatures of Eastern Mediterranean sapropels, Palaeogeogr. Palaeocl., 158, 293-309, 2000.

Wehausen, R. and Brumsack, H.-J.: Cyclic variations in the chemical composition of Eastern Mediterranean Pliocene sediments: A key for understanding sapropel formation, Mar. Geol., 153, 161-176, 1999.

Weldeab, S., Emeis, K.-C., Hemleben, C., Schmiedl, G., and Schulz, H.: Spatial productivity variations during formation of sapropels S5 and S6 in the Mediterranean sea: Evidence from Ba contents, Palaeogeogr. Palaeocl., 191, 169-190, 2003a.

Weldeab, S., Siebel, W., Wehausen, R., Emeis, K.-C., Schmiedl, G., and Hemleben, C.: Late Pleistocene sedimentation in the Western Mediterranean Sea: Implications for productivity changes and climatic conditions in the catchment areas, Palaeogeogr. Palaeocl., 190, 121-137, 2003b. 